Management Accounting Research, Volume 23, Issue 2, June 2012, Pages 79-19

\title{
Contemporary performance measurement systems: A review of their consequences and a framework for research
}

\author{
Monica Franco-Santos ${ }^{1}$ \\ Cranfield School of Management \\ Cranfield University \\ Cranfield, Bedfordshire, MK43 0AL \\ Tel. +44(0) 1234751122 \\ Fax: +44(0) 1234754332 \\ Email: monica.franco@cranfield.ac.uk \\ Lorenzo Lucianetti \\ Department of Management and Business Administration \\ University of Chieti and Pescara \\ Viale Pindaro 42, 65127 Pescara (Italy) \\ Tel: +39085 4537603 \\ Fax: +390854537603 \\ Email: 1lucianetti@unich.it \\ Mike Bourne \\ Cranfield School of Management \\ Cranfield University \\ Cranfield, Bedfordshire, MK43 0AL \\ Tel. +44(0) 1234751122 \\ Fax: +44(0) 1234754332 \\ Email: m.bourne@cranfield.ac.uk
}

March 2012

Contemporary performance measurement systems: A review of their consequences and a framework for research

${ }^{1}$ Corresponding author 


\begin{abstract}
The main purpose of this paper is to develop a conceptual framework for understanding the literature on the consequences of contemporary performance measurement (CPM) systems and the theories that explain these consequences. The framework is based on an indepth review of 76 empirical studies published in high-quality academic journals in the areas of accounting, operations, and strategy. The framework classifies the consequences of CPM into three categories: people's behaviour, organizational capabilities, and performance consequences. This paper discusses our current knowledge on the impact of CPM, highlighting inconsistencies and gaps as well as providing direction for future research.
\end{abstract}

\title{
Keywords
}

Contemporary performance measurement systems, balanced scorecard, levers of control framework, strategic performance measurement systems, key performance indicators, diverse performance measures

\section{Introduction}

The use of performance measurement systems is frequently recommended for facilitating strategy implementation and enhancing organizational performance (e.g., Davis and Albright, 2004). Today, contemporary performance measurement (CPM) comprises the use of financial as well as non-financial performance measures linked to the organization's business strategy. 
For instance, balanced scorecards (BSC) (Kaplan and Norton, 2001) and multi-criteria key performance indicators (KPI) can be considered CPM systems (Cheng et al., 2007; Hall, 2008). The adoption of this type of system has increased steadily in the last two decades (Rigby and Bilodeau, 2009). Organizations are under great pressure to deliver value not only to their shareholders but also to other stakeholders, and they believe CPM systems can help them in this task (Ittner and Larcker, 2001, 2003). This may explain why many organizations are investing heavily in the development and maintenance of CPM systems (Neely et al., 2008). From a research point of view, we have some knowledge about why organizations adopt these systems (e.g., Chenhall and Langfield-Smith, 1998; Henri, 2006a; Hoque and James, 2000). We are, however, less knowledgeable about their actual consequences (Lee and Yang, 2010).

Accounting, operations, and strategy researchers have examined the effects of CPM systems. Researchers have used an array of research methods, such as case study research (e.g., Bititci et al., 2006; Kolehmainen, 2010), survey research (e.g., Burney and Widener, 2007; Cheng et al., 2007; De Waal et al., 2009), quasi-experimental research (e.g., Davis and Albright, 2004; Griffith and Neely, 2009), and experimental research (e.g., Lipe and Salterio, 2000, 2002; Tayler, 2010). Researchers have focused on different levels of analysis. For instance, the work of Hall $(2008,2010)$ focuses on how CPM systems affect the behaviour and performance of individuals, whilst the work of Scott and Tiessen (1999) concentrates on how CPM systems affect team performance. Researchers have also investigated the effects of CPM systems taking into consideration aspects such as their particular design, implementation, or use (e.g., Speckbacher et al., 2003). Nevertheless, there is still a lack of consensus on the actual consequences of CPM. Furthermore, to our knowledge, no integration study has been conducted to better understand the diverse effects of CPM systems as well as how these effects occur. Integrating our research knowledge in this area is 
important to progress the CPM field and to support evidence-based management initiatives (Rousseau, 2006).

The aim of this paper is to integrate our knowledge on the consequences of CPM systems by conducting a review of the existing empirical evidence on this topic. Specifically, we pursue two objectives. Our first objective is to identify and categorize the consequences of CPM systems studied in the literature, providing a guiding framework that integrates them. We classify the consequences of CPM into three categories: people's behaviour, organizational capabilities, and performance consequences. This comprehensive yet parsimonious categorization allows us to accommodate the numerous variables that may be affected by CPM systems, thereby facilitating the understanding of this complex phenomenon. Our category encompassing people's behaviour refers to consequences related to the actions or reactions of employees (e.g., motivation, participation) and their underlying cognitive mechanisms (e.g., perceptions). Our organizational capabilities category refers to consequences associated with specific processes, activities, or competences that enable the organization to perform and gain competitive advantages (e.g., strategic alignment, organizational learning). Finally, our performance category comprises the different effects that CPM systems can have on financial and non-financial results at all levels of the organization (e.g., firm performance, managerial performance, and team performance).

Our second objective is to explain the different mechanisms by which CPM is presumed to affect people's behaviour, organizational capabilities, and performance. In the literature, several theories have been proposed to explain the consequences of CPM. Theories such as agency theory and goal-setting theory present strong arguments as to how the use of CPM affects behaviour and motivation. However, there are other less widely used theories that have also been adopted in the literature and deserve some attention. For instance, Schiff and Hoffman (1996) use attribution theory to explain how executives use multi-criteria 
performance measures and how these measures affect their decision-making processes. Another example is the work of Malmi (2001), who adopts neo-institutionalism theory to explain why companies adopt CPM systems and the consequences of these decisions. Understanding the underlying mechanisms that generate the different consequences of CPM is critical for determining how to maximize the effectiveness of these systems.

The remainder of this paper is structured as follows. In section 2, we provide a definition of CPM and a full description of the three categories of CPM effects. In section 3, we discuss our method of literature review, explaining in detail the process adopted and our research selection criteria. In section 4, we present our framework for research, comprising the findings of our literature review. In section 5, we discuss the findings of our review, along with their implications for practice and suggestions for further research. We also outline here the limitations of our study. Finally, in section 6, we draw our research conclusions.

\section{Defining Contemporary Performance Measurement Systems}

Before conducting a review of the consequences of CPM systems, we first need to clarify what we mean by CPM systems. Most scholars define $\mathrm{CPM}^{2}$ systems in terms of their features. For example, Cheng et al. (2007) hold that "contemporary performance measurement systems, such as the balanced scorecard, advocate the use of an array of financial and non-financial performance measures" (p. 221). Other scholars have defined CPM systems not only in terms of their features but also in terms of their role or main processes. For instance, Hall (2008) defines CPM as a system that "translates business

\footnotetext{
${ }^{2}$ It is important to note that in the literature, the phrase "contemporary performance measurement" is often used interchangeably with other phrases such as "integrated performance measurement" (Bititci, Carrie, and McDevitt, 1997), "comprehensive performance measurement" (Hall, 2008), "strategic performance measurement” (Burney and Widener, 2007; Ittner, Larcker, and Randall, 2003), or "business performance measurement" (McAdam and Bailie, 2002).
} 
strategies into deliverable results [...] combining financial, strategic and operating business measures to gauge how well a company meets its targets" (p. 43). Similarly, Ittner, Larcker, and Randal (2003) suggests that CPM "provides the information [financial as well as nonfinancial] that allows the firm to identify the strategies offering the highest potential for achieving the firm's objectives, and aligns management processes, such as target setting, decision-making, and performance evaluation, with the achievement of the chosen strategic objectives" (p. 715). As there are different perspectives used to study CPM systems, the literature lacks an agreed definition. This issue creates confusion, limiting the potential for researchers to compare different studies in this field.

To overcome this limitation and facilitate our review, we follow the approach suggested by Franco-Santos et al. (2007). We clarify the definition of a CPM system by focusing on its necessary and sufficient conditions. We argue that a CPM system exists if financial and nonfinancial performance measures are used to operationalize strategic objectives. This definition is based on a number of assumptions. Firstly, the definition assumes that the role of $\mathrm{CPM}$ systems is to evaluate performance for either informational or motivational purposes (regardless of the organizational level at which performance is evaluated). Secondly, it assumes that CPM systems comprise a supporting infrastructure, which can vary from being a simple method of data collection and analysis (using, for example, Excel) to a sophisticated information system facilitated by enterprise resource planning platforms or business intelligence solutions. Finally, it assumes that CPM systems involve specific processes of information provision, measure design, and data capture, regardless of how these processes are conducted.

According to the definition proposed, systems such as those based on the BSC (Kaplan and Norton 1992, 1996, 2001), the performance prism (Neely et al., 2002), or the levers of control framework (Simons, 1995) are considered CPM systems. Performance measurement 
systems adopting diverse KPIs are also considered CPM systems, provided that the KPIs are linked to the organization's business strategy. However, systems such as traditional budgeting systems or activity-based costing systems will not be considered CPM systems, mainly because they focus on cost drivers that are measured in financial terms only. Thus, they do not meet the requirement of having both financial and non-financial performance measures.

\section{Classifying contemporary performance measurement systems}

A definition is helpful for clarifying what a CPM system is and what it is not. Speckbacher et al. (2003) argue that a single definition does not capture the complex nature of these systems. They suggest that for research purposes a comprehensive typology should be used instead. In their study of German-speaking organizations they find that these organizations use three different versions of BSC. Some organizations have a BSC type I, which is a scorecard containing financial and non-financial strategic performance measures grouped into perspectives. Others have a BSC type II, which is a scorecard type I that employs a specific approach to describe the organization's strategy using a sequential causeand-effect logic to link tangible and intangible assets. These cause-and-effect linkages have been called mental models (Eccles and Pyburn, 1992), strategy maps (Kaplan and Norton, (2000), and success maps (Neely et al., 2002). Finally, a set of organizations adopts a BSC

type III, which is a scorecard type II with an additional feature that makes incentive pay contingent on the performance results of the scorecard measures. Based on their findings, Speckbacher et al. (2003) suggest that further research take into consideration these three types of scorecard systems. 
Speckbacher et al.'s typology is considered by many researchers as a useful tool for understanding the effects of CPM systems (e.g., Lee and Yang, 2010). Despite its strengths, however, we were unable to use it in our research. There were two reasons for this. Firstly, Speckbacher et al.'s typology focuses on BSCs in particular, whilst our literature review looks at CPM systems in general. Secondly, Speckbacher et al.'s typology advocates that the three types of BSC are incrementally related, whilst we find that this might not necessarily be the case. For instance, in our review of the literature we find that many researchers look at the impact of linking financial and non-financial strategic performance measures to incentive pay without necessarily taking into consideration the adoption of cause-and-effect relationships among the measures (e.g., Ittner, Larcker, and Meyer, 2003), which is a necessary condition required to meet the specifications of Speckbacher et al.'s BSC type III. Thus, we adapted Speckbacher et al.'s typology to our research needs. As a result, we use a CPM typology where the first two types of our CPM systems are similar to Speckbacher et al.'s types I and II, but the rest differs. We describe our typology here to elucidate how we classify our findings and present the variables and relationships studied.

Four CPM system types have been identified ${ }^{3}$. The description of each type of CPM focuses on the components (part 1 of the description) and on the key purpose (part 2 of the description) of these systems. Some researchers focus on the consequences of performance measurement systems that (1) include financial as well as non-financial performance measures implicitly ${ }^{4}$ or explicitly linked to strategy and (2) are used to inform managerial

\footnotetext{
${ }^{3}$ To validate our classification, we contacted the authors of the selected studies by email. We asked them to agree or disagree with the category in which we had placed their study and to provide us with additional comments if required. The authors of 60 studies responded to our email. The authors of 58 studies agreed with our classification. The authors of two studies were unsure about the way in which we had classified their work and provided us with additional comments. We considered their comments and further refined the description of each of our CPM categories.

${ }^{4}$ The term implicit refers to implied but not plainly expressed or assessed in the research. For example, we find that many researchers explore the impact of balanced scorecards by focusing on the use of financial as well as
} 
decision-making and to evaluate organizational performance. We label this first type of CPM system as type $\mathrm{A}^{5}$. Other researchers examine the consequences of performance measurement systems that (1) include financial as well as non-financial performance measures linked to strategy, showing explicit cause-and-effect relationships among the measures; and (2) are used to inform managerial decision-making and to evaluate organizational performance. We label this second type of CPM system as type B. Researchers also concentrate on the consequences of performance measurement systems that (1) include financial as well as nonfinancial performance measures implicitly or explicitly linked to strategy and (2) are used to inform decision-making and evaluate organizational and managerial performance (without linking the performance evaluation results to monetary rewards). We label this third type of CPM system as type C. Finally, researchers have investigated the consequences of performance measurement systems that (1) include financial as well as non-financial performance measures implicitly or explicitly linked to strategy and (2) are used to inform decision-making, evaluate organizational and managerial performance, and influence monetary rewards. We label this fourth type of CPM system as type D.

\section{INSERT TABLE 1}

\section{Method}

To meet our research objectives, we conducted our study with the following research questions in mind: (1) What are the consequences of CPM systems? (2) What theories have been used to explain the consequences of CPM systems? We performed our literature review

non-financial performance measures assuming that those measures are aligned to the business strategy (e.g., Hoque and James, 2000).

${ }^{5}$ We used a different nomenclature to the one used by Speckbacher et al. (2003) to avoid confusion. 
following a six-step process. First, we conducted a scoping study based on an ad hoc list of empirical papers that focus on the consequences of CPM systems. Second, we searched the literature and identified the relevant studies for our review. Third, we selected those studies that met our specific selection criteria. Fourth, we read the papers selected and developed a data set including the main variables ${ }^{6}$ and characteristics of each study. Fifth, we classified the effects of CPM systems. Finally, we synthesized the insights extracted from the literature review in order to answer our research questions. The following sub-sections provide an overview of how the review process was developed.

\subsection{Scoping study and selection of relevant literature}

Our first step in the literature review process was to conduct a scoping study. The purpose of this study was to identify the key sources of research, the type of evidence available, and the main keywords required for finding relevant studies. The list of papers used for the scoping study was created based on our knowledge of the topic and on discussions with academic experts in the area of performance measurement and management. This list included the work of Ahn (2001), Cavalluzo and Ittner (2004), Davis and Albright (2004), Decoene and Bruggeman (2006), Evans (2004), Godener and Soderquist (2004), Griffith and Neely (2009), Ittner, Larcker, and Meyer (2003), Ittner, Larcker, and Randall (2003), Johnston et al. (2002), Lingle and Schiemann (1996), Lipe and Salterio (2000, 2002), and Papalexandris et al. (2004). We analysed these papers and their references. We found that most research on CPM came from three different research disciplines: management accounting, operations management, and strategy. This research referred to both public and

\footnotetext{
${ }^{6}$ We use the word "variable" in general terms to refer to "what a study is about" (Luft and Shields, 2003, p. 173). We examine conceptual variables or constructs (expressed in abstract terms and used in theory building research) as well as measured variables (expressed in numerical terms and used in theory testing research) (Stangor, 2010).
} 
private sector organizations. We also found that the keywords that could help us to find relevant studies were "performance measure*", "balanced scorecard", and "management control*"

Based on the insights extracted from our scoping study, we defined the criteria for selecting those studies that would constitute the data set for our literature review. The main objective of these criteria was to narrow the scope of our research and allow its replication. These criteria are described as follows:

- We chose fifteen journals as the main source of our research. We selected five key journals in accounting (ACC), five key journals in operations (OPS), and five key journals in strategy/general management (STR/MNG). The selected journals were Accounting, Organization and Society; The Accounting Review; Management Accounting Research; Behavioral Research in Accounting; British Accounting Review; Journal of Operation Management; Operations Research; International Journal of Operations and Production Management; International Journal of Production Research; International Journal of Production Economics; Long Range Planning; Strategy Management Journal; Academy of Management Journal; Administrative Science Quarterly; and British Journal of Management. We selected these journals because, according to our scoping study, they are the more likely to publish research on CPM, and they are regarded as being of high quality within each of the disciplines included in the review.

- Selected studies could also come from the references included in the papers found in any of the above journals. We chose this criterion to avoid missing relevant studies

\footnotetext{
${ }^{7}$ The truncation character, *, is used to find articles containing words with the same root. For example, a search for performance measure* will find articles containing the words "measures", "measurement", and "measurements".
} 
published in journals other than the ones included in our review. However, to preserve the quality of our literature sources, if the paper found in the references was published in a journal with less than two stars according to the ABS Academic Journal Quality Guide (2010), the paper was excluded from the review for quality reasons.

- The studies included in the review had to provide empirical evidence on the consequences of CPM in for-profit organizations regardless of the qualitative or quantitative nature of their data. To narrow the focus of our review, empirical work from not-for-profit and government organizations together with theoretical or conceptual papers were considered to be out of scope.

- The review took into consideration published work from 1992 to October 2011. The main reason for choosing 1992 as a cut-off point was the publication in that year of the BSC framework (Kaplan and Norton, 1992), which has been considered crucial for the development of CPM research (Neely, 2005).

- If some portions of a study met the selection criteria stated above and others did not, only the portions that met the criteria were included in the review. The portions that did not meet these criteria were omitted. For instance, if a research paper presents the consequences of CPM systems together with the consequences of other management systems, only the results related to CPM are included in this review.

After defining our selection criteria, we searched the literature in three electronic databases, namely, ISI Web of Knowledge, EBESCO, and ABI Proquest, using the keywords identified through the scoping study and the names of the fifteen selected journals. We conducted our searches in three different databases to maximize our likelihood of finding relevant studies and to improve the reliability of our research. The studies identified were downloaded, and the key information was extracted from each paper for analysis in 
referencing software. We read the abstracts and selected the papers that met our selection criteria. We then downloaded the full manuscripts and identified further relevant research through the cross-references.

Whilst reading the papers we created a summary table including the main attributes of each study (see Table A.1 in the Appendix). This table captured the authors' names, date the study was published, area of research (accounting, strategy/general management or operations), type of CPM system studied (A, B, C, or D) including specific information regarding the CPM framework used (e.g., BSC, levers of control (LoC), or KPIs), underpinning theory or theories used to explain the CPM consequences, methods of data collection and analysis, consequences of CPM systems, variables that moderate the different consequences of CPM systems, industry and country where the research took place, and the level of analysis used in the research (individual, team, department, business unit, division, organization, and beyond the organization level). We classified the selected studies according to their research method and then in alphabetical order based on the name of the first author.

It must be noted that when reviewing quantitative studies exploring mediation relationships, we classified as consequences of CPM systems both mediators and dependent variables. For example, in Hall's (2008) study role clarity and psychological empowerment mediate the relationship between the use of CPM systems and managerial performance. In this literature review we considered these three variables as consequences of CPM systems. Role clarity and psychological empowerment are intermediate consequences. Managerial performance is an ultimate consequence.

\subsection{Conceptual framework and classification of consequences}

After extracting the main attributes of each selected study in Table A.1 (Appendix), we constructed Tables 3 to 5 to organize our findings and to help us create our conceptual 
framework (shown in Figure 1). This framework groups the CPM consequences into three different categories: consequences for people's behaviour, consequences for organizational capabilities, and consequences for performance. Consequences for people's behaviour comprise specific actions or reactions of people to CPM systems as well as their underlying cognitive mechanisms. Examples of these variables are motivation, perceptions, and cooperation. Consequences for organizational capabilities involve specific processes, activities, or competences that enable organizations to gain competitive advantage - for example, organizational learning or innovativeness. Finally, consequences for performance include the effects of CPM systems on financial as well as non-financial results. For instance, variables such as managerial performance, market performance, and financial performance are all considered performance consequences. Besides classifying the consequences of CPM systems according to our framework, we also took note of the internal and external contextual factors that were found to affect these consequences and of the potential areas in the literature that needed further research. In the next section, we describe the results of our review using our conceptual framework as a guiding tool.

\section{INSERT FIGURE 1}

\section{Findings}

We found 76 papers that met our review selection criteria. Table A.1 (Appendix) summarizes the key characteristics of these studies. Table 2 classifies the studies according to the type of CPM system studied and the research method used. We present the findings extracted from this review following the conceptual framework that appears in Figure 1. We 
first describe the different consequences of CPM researched in the literature in terms of people's behaviour, organizational capabilities, and performance. We then state and discuss the theories that have been used to explain the effects of CPM. In this section, we avoid referencing to each of the individual types of CPM systems unless we find contradicting evidence that requires further explanation. Nevertheless, Tables 3 to 5 summarize the CPM system consequences for people's behaviour, organizational capabilities, and performance according to each of the CPM systems studied.

\section{INSERT TABLES 2}

\subsection{Consequences for people's behaviour}

The adoption of CPM systems affects the behaviour of people in a number of ways (see Table 3). The following sub-sections explain these types of consequences in detail.

\subsubsection{Strategic focus}

Researchers agree on the effect that CPM systems have on people's strategic focus. They suggest that the use of a CPM system improves executives' discussions about strategy and helps to concentrate the efforts of executives on what is important for the organization. The studies finding this consequence have mainly been based on qualitative data (e.g., Ahn, 2001; Butler et al., 1997; Jazayeri and Scapens, 2008; Sandstrom and Toivanen, 2002). In quantitative studies, the impact of CPM systems on people's strategic focus is often used as one of the main supporting arguments explaining how the CPM system is able to affect performance. It is interesting to note, however, that none of the quantitative studies found in this literature review convert the conceptual variable of "strategic focus" into a measured 
variable of "strategic focus". Further quantitative research looking at the relationship between CPM systems and people's strategic focus could help us to better understand this effect.

\subsubsection{Cooperation, coordination, and participation}

Researchers have also focused on the effect of CPM systems on cooperation, coordination, and participation, not only within the organization (among individuals, teams, or business units) but also beyond the organization (e.g., among buyers and suppliers). Two studies look at the effect of CPM systems on relationships beyond the boundaries of the organization (Mahama, 2006; Cousins et al., 2008). Mahama (2006) finds evidence suggesting that CPM systems facilitate cooperation and socialization in supply relationships. Mahama's (2006) research shows that the CPM system helps ensure that performance information is distributed fairly among participants in the supply relationship, which enables learning and problem solving. This aligns the interests of the relationship participants, making them more willing to adapt to changes when necessary while avoiding the exercise of power. Cousins et al. (2008) support Mahama's (2006) findings and show that the use of CPM systems enhances communication in buyer-supplier relationships, which in turn improves socialization.

Looking at the impact of CPM systems on relationships, we find a number of studies. Cruz et al. (2011) focus on globally dispersed sub-units and find that the use of a CPM system provides better coordination and control among them. Dossi and Patelli (2010) investigate the relationships between head offices and subsidiary companies in multinational organizations, demonstrating that the use of CPM systems enhances their relationships. Papalexandris et al. (2004), researching a particular company in a case study, find that the development of a BSC system improved the relationships of employees from different divisions, who in the past worked competitively against each other due to the way 
performance measures and targets were set. Wiersma's (2009) survey supports Papalexandris' (2004) qualitative results as he shows that managers find CPM systems useful for coordinating activities within and among departments. In sum, the evidence suggests that CPM systems are useful devices for improving cooperation and coordination among people within the organization and outside the organization with its partners.

Related to the CPM effect on cooperation is the effect of CPM systems on employee participation and involvement. Butler et al. (1997) observe how the iterative and consultative process required for the development and implementation of CPM systems enhances participation. This finding is aligned with the work of Kolehmainen (2010), Papalexandris et al. (2004), and Sandstrom and Toivanen (2002), which suggests consensus regarding the positive impact of CPM systems on employee involvement in the organization's performance measurement and management process.

\subsubsection{Motivation}

Research on the motivational effect of CPM systems has produced mixed results. The case studies conducted by Papalexandris et al. (2004) and Sandstrom and Toivanen (2002) show that CPM systems improve people's motivation towards the achievement of strategic objectives. In particular, Godener and Soderquist (2004) find that the degree of employee motivation generated is influenced by the degree of participation in the measurement process. However, the studies of Malina and Selto (2001) and Decoene and Bruggeman (2006) show that the adoption of a CPM system may actually have negative effects on motivation, especially when the system's performance measures are used to determine bonus payments. Malina and Selto (2001) argue that CPM stimulates motivation when two conditions exist. Firstly, the CPM system must be an effective management control device, including performance measures and targets that are controllable, challenging but attainable, and 
related to meaningful rewards. Secondly, the CPM system must be supported by an effective communication mechanism that encourages feedback, dialogue, and participation. Decoene and Bruggeman (2006) suggest that the use of CPM systems to influence monetary rewards can negatively affect motivation if the performance measures used have low strategic alignment, controllability, timeliness, and technical validity.

Additionally, researchers have explored the impact of CPM systems on intrinsic task motivation referred to as psychological empowerment. For instance, Hall's (2008) survey research looks at the effect of CPM systems on the psychological empowerment of managers in a set of four cognitions: (1) meaning (the value placed on work based on people's own standards); (2) competence (people's belief in their capacity to perform a job well); (3) selfdetermination (people's belief about the degree of autonomy allowed in their jobs); and (4) impact (the extent to which people believe they can influence their job outcomes). He finds that CPM systems influence the cognition and motivation of managers through the effects on the managers' psychological empowerment manifested in the four cognitions studied.

Related to the work of Hall (2008) is the experiment conducted by Webb (2004) on the impact of CPM on the motivation of managers to meet their goals - defined by Webb as 'goal commitment'. Webb demonstrates that the use of a CPM system containing strong cause-andeffect relationships among its financial and non-financial performance measures (i.e., CPM type B) increases the managers' perceptions of self-efficacy and goal attractiveness (anticipated satisfaction from goal achievement). As a result, the motivation of managers to meet their financial and non-financial performance goals is strengthened.

In sum, the evidence suggests that it is as much the process of developing and using the CPM system, as it is the resultant performance measures that yield motivational benefits. To drive motivation the CPM system should be developed and used in a way that enhances the 
employees' participation, psychological empowerment, and goal commitment (through increased perceptions of self-efficacy and goal attractiveness). The CPM system should also comprise performance measures that are strategically aligned, controllable, timely, and technically valid. An issue that remains unresolved is the extent to which the link between performance measures and bonus payments is desirable based on the negative data found by Malina and Selto (2001) and Decoene and Bruggeman (2006).

\subsubsection{Citizenship behaviours}

Burney et al. (2009) explore the effects that CPM systems have on organizational citizenship behaviours (OCB), which are behaviours above and beyond the requirements of the job. They find that the adoption of CPM type D positively affects employees' OCBs through the positive impact the use of this system has on procedural justice. This area of enquiry deserves more attention, as the positive behavioural effects of CPM type D found by Burney et al. (2009) contrast with the effects found by other researchers such as Malina and Selto (2001) or Ittner, Larcker, and Meyer (2003).

\subsubsection{Role understanding and job satisfaction}

There is evidence suggesting that CPM systems affect the extent to which people understand their role requirements and are satisfied with their jobs. Regarding the effect of CPM systems on role understanding, the surveys of Burney and Widener (2007), Hall (2008), and Cheng et al. (2007) are highly relevant. Burney and Widener (2007) find that the adoption of CPM type B systems facilitates the provision of job-relevant information, which in turn decreases people's perception of role conflict (inability to fulfil job expectations due to incompatible demands) and role ambiguity (unclear information about job duties, authority, and responsibilities). However, they conduct further tests and point out that (a) the association between the adoption of a CPM type B system and reduced role conflict occurs 
when there is a low level of complexity in the CPM system (the number of performance measures included is approximately 10 or less); (b) the association between CPM type B and the provision of job-relevant information is less important for managers with moderate experience (8.4 years) than it is for managers with low (2.2. years) or high experience (20 years); and (c) the association between CPM type B and reduced role ambiguity is significant when the system is used for determining pay (i.e., when the system adopted is what we have defined as a CPM type D).

Hall's (2008) research finds similar results to Burney and Widener (2007). In his survey of 83 business unit managers, he finds that CPM type B systems increase managers' perceptions of role clarity (the beliefs of individuals about the expectations and behaviours associated with their work role). Hall argues that this effect occurs because the CPM system provides managers with performance information that increases their knowledge of the organization's strategic goals, and helps them to better understand the potential effects of their actions on the organization's value chain.

In contrast, Cheng et al. (2007) suggest that the use of CPM systems for individual performance evaluation purposes (i.e., CPM type C) can affect individuals' perceptions of goal conflict (the degree to which individuals feel that performance expectations are incongruent). They argue that individuals have a limited cognitive capacity, so when they are assigned multiple goals (such as the ones included in a CPM system) they may not be able to cope with the incompatible demands of these goals. Hence, goal conflict will appear and the attainment of one particular goal may come at the expense of failing to achieve other goals. They find that the extent to which CPM systems influence goal conflict depends on the individuals' level of perceived overall goal difficulty (perceptions of high levels of goal difficulty lead to higher levels of goal conflict). 
Thus, the evidence suggests that the information included in CPM systems is likely to increase the understanding of individuals regarding what is expected from them at work. However, this impact is highly dependent on the CPM system's design characteristics (complexity and links with pay) and individual characteristics (individuals' experience and perceptions of goal difficulty).

Lau and Sholihin (2005) investigate the influence of CPM systems on job satisfaction. Using survey data, they show that the use of CPM systems increases employee job satisfaction when employees trust their supervisor and perceive fairness in the way performance is evaluated. Further research could use the knowledge developed by Burney and Widener (2007), Hall (2008), and Cheng et al. (2007), and combine it with the work of Lau and Sholihin (2005), adding new unexplored variables suggested in the psychology literature (e.g., Saari and Judge, 2004) such as 'job intrinsic characteristics' (e.g., the extent to which the use of CPM systems increases the satisfaction of employees with the nature of the work itself, which includes job challenge, autonomy, variety and scope), 'life satisfaction', or 'stress' (e.g., the extent to which the characteristics of the different CPM systems increase stress levels and negatively affect employee well-being).

\subsubsection{Decision making, learning, and self-monitoring}

The impact of CPM systems on managers' decision-making processes, learning, and selfmonitoring has also received attention in the literature. Research evidence suggests that CPM systems help managers learn about how to best improve their performance when appropriate feedback mechanisms are in place (Tuomela, 2005). CPM systems also help managers confirm their mental models of how their business operates; in particular, for managers with low experience and/or from small-sized business units, CPM systems may also enable them to build new mental models (Hall, 2010). Wiersma (2009) finds that managers consider CPM 
systems useful for self-monitoring their own performance and for making decisions. Grafton et al. (2010) extend previous work in this area and point out that the extent to which the measures included in the CPM system are captured in performance evaluation mechanisms (i.e., CPM type C) will significantly influence the use of those measures for decision making.

In sum, the data found shows that CPM systems influence managers' cognitive processes. The extent to which they do so depends on the way the CPM system is developed and used, on the idiosyncrasies of the organization, and on the managers' individual characteristics.

\subsubsection{Leadership and culture}

CPM systems may shape leadership styles, individual routines, and organizational cultures. Bititci et al. (2006), Jazayeri and Scapens (2008), and Ukko et al. (2007) investigate these particular consequences of CPM systems using case study research. Bititci et al. (2006) observe that the successful implementation and use of CPM systems leads to cultural change and to a more participative and consultative leadership style. Jazayeri and Scapens' (2008) research examines the specific use of a CPM system as part of a cultural change project. They find that the CPM system supported the cultural change by reinforcing the desired behaviours, values, and beliefs. Lastly, Ukko et al. (2007) observe that the use of a CPM system improves the quality and content of the conversations managers have with employees (processing and dealing with work issues becomes easier), brings about new routines (e.g., the case company established a number of new meetings at all levels of the organization with the purpose of engaging managers and employees in the performance reviewing process), and enhances information sharing. All of which, eventually, alters the organization's culture. In parallel, the organizational culture moderates the effects of CPM systems, which resonates with Bititci et al.'s (2006) finding and Henri's (2006a) work. Hence, these studies suggest that CPM systems are powerful tools for bringing about change and new ways of managing 
people in organizations, but they are also subject to the effects that the organizational culture may have on them.

\subsubsection{Satisfaction}

Some scholars have assessed the degree to which people are satisfied with the use of CPM systems as a way of examining the effectiveness of such systems. Studies find that individuals are satisfied with the use of CPM systems at least in the short term, which is when satisfaction is mainly assessed. This is the case in the survey work conducted by Ittner, Larcker, and Randall (2003) and Speckbacher et al. (2003), and the case studies carried out by Malmi (2001) and Jazayeri and Scapens' (2008). However, this finding deserves some caution as these research studies are based on single respondents from the finance or accounting function, which tend to be the functions that promote the development and use of CPM systems. These managers are more likely to exhibit the "ownership" bias (Shields, 1995), especially when they are the main sponsors of the CPM system (Foster and Swenson, 1997). In fact, Ittner, Larcker, and Meyer's (2003) research conducted with multiple respondents from the same organization shows that CPM systems may also generate dissatisfaction among employees due to the increased perceptions of unfairness generated by the system. This is reviewed in the next sub-section.

\subsubsection{Perceptions of subjectivity, justice, and trust}

Numerous researchers agree on the fact that CPM systems bring in subjectivity, but the extent to which this subjectivity is helpful or not is still debatable. Ittner, Larcker, and Meyer's (2003) research was the first to note that the use of CPM systems for evaluation and pay purposes (i.e., CPM type D systems) increases the managers' perceptions of subjectivity and uncertainty. This is a direct result of the difficulty in assessing many non-financial performance dimensions using objective metrics. These perceptions of subjectivity and 
uncertainty increase managers' complaints and question the validity and usefulness of the whole system. Likewise, Papalexandris et al. (2004) find that some managers are uneasy with the subjectivity associated with the linkages between the objectives displayed in strategy maps, which leads to continuous arguments about the actual correlations among the selected strategic goals. Contrary to previous work, Kolehmainen (2010) shows with a longitudinal case study that the subjectivity created by the CPM system can be perceived as a good outcome, because it enables the firm to be more flexible and adapt more rapidly to environmental and internal changes. This is an important finding, as it suggests that the positive or negative attitude towards subjectivity depends on the particular characteristics of the organization studied.

Burney et al. (2009) extend our knowledge on the impact of CPM systems on subjectivity by looking at a set of factors that affect employees' perceptions of justice. They suggest that subjectivity is more problematic when the CPM system is used to decide monetary rewards (i.e., CPM type D). They argue that the perceptions of justice by employees are influenced by two specific characteristics of a D-type CPM system: (a) the system reflects a strategic causal model (it includes cause-and-effects relationships among the organizations' strategic goals), and (b) the system is technically valid (its measures are accurate, accessible, understandable, reliable, and timely). They show that organizations can address issues of subjectivity and improve the organizational citizenship of individuals by communicating the attributes of the CPM system in a way that employees perceive the system to have a high degree of technical validity and that reflects the organization's value chain. In line with the findings of Burney et al.'s (2009) study, Lau and Sholihin (2005) find that organizations with well-defined and specified performance measures, regardless of whether they are financial or non-financial, engender higher levels of procedural justice and trust in supervisors, which subsequently generates higher levels of employee job satisfaction. 
Overall, research on the impact of CPM systems on subjectivity needs further development. When subjectivity is understood as perceptions of unfairness, existing evidence suggests that employees might be disappointed with the use of CPM systems. However, when subjectivity is perceived in terms of flexibility, the data show that CPM systems can help organizations deal with change. Further research looking at this effect could explore the contextual factors that enable organizations to find benefits from perceived subjectivity or develop mechanisms to minimize people's negative attitudes towards subjectivity.

\subsubsection{Judgement biases}

A large body of literature, mainly based on experiments with management students, has documented the specific performance evaluation biases that emerge with the adoption of CPM systems. The initiators of this body of research are Lipe and Salterio (2000). They examine how the BSCs of business units that include common and specific measures affected the superior's evaluation of the unit's performance. Evaluators made performance decisions based on the measures common across the business units. These were likely to be financial measures. Evaluators disregarded the unique measures, which were likely to be non-financial measures. In a subsequent experiment, Lipe and Salterio (2002) extend their work and show how the way in which measures are organized in the BSC also affects superiors' judgements.

More recent research looking at the impact of BSCs on managers' judgement has replicated Lipe and Salterio's $(2000,2002)$ studies and has focused on identifying tools and actions that may reduce the evaluator's bias. The following tools and actions have been proposed as being potentially beneficial for reducing judgement biases: using an independent third-party assurance report and requiring managers to justify their performance evaluations to their superior (Libby et al., 2004); providing evaluators with full information about the organization's strategic objectives and other related knowledge such as cause-and-effect 
relationships among the measures or the way in which the scorecard has been developed (Banker et al., 2004; Cardinaels and Van Veen-Dirks, 2010; Dilla and Steinbart, 2005); and following a "disaggregation-plus-mechanical-aggregation" approach for presenting and evaluating performance results (Roberts et al., 2004).

Some scholars have investigated moderating variables that influence the extent to which CPM systems generate judgement biases: Liedtka et al. (2008) examine the importance of the performance evaluator's level of ambiguity intolerance; Wong-on-Wing et al. (2007) study the effect of the evaluator's managerial role; and Kaplan and Wisner (2009) review the consequences of using different ways of presenting the measures. Other scholars have paid specific attention to the relationship between the performance evaluation of non-financial performance measures and more compressed or lenient performance ratings (Moers, 2005), and to other judgement biases such as the bias that may occur when selecting strategic initiatives (Tayler, 2010) or using the scorecard measures for determining bonus payments (Dilla and Steinbart, 2005; Roberts et al., 2004).

In conclusion, it can be argued that CPM systems are likely to generate performance judgement biases mainly due to their complexity and the subjective nature of some of the measures used. The evidence also suggests a number of approaches to reduce the occurrence of these biases. However, further research in this area is encouraged as other literatures (e.g. psychology and sociology) have found additional individual and team judgement biases associated with information processing that have not been yet considered with the use of CPM systems. For instance, most of the current work has looked at the judgement biases that occur when assessing performance. There might be other types of biases that also occur when the CPM system is being designed. One of these biases may be the 'hindsight bias' (the inclination to see events that have already occurred as being more predictable than they were 
before they took place) (Fischhoff and Beyth, 1975). This bias may be present when causeand-effect relationships are created, but to our knowledge no research to date has looked at it.

\subsubsection{Conflicts and tensions}

CPM systems may create conflicts and tensions among individuals and teams. Malina and Selto (2001), for example, describe how the one-way reporting adopted in a BSC case study generates tensions that contribute to a climate of distrust and alienation. Marginson (2002) suggests that top management's use of CPM systems creates tension, especially during the actual development of new measures, ideas, and initiatives. Tuomela's (2005) case study shows that some managers are reluctant to use CPM systems, as these systems increase their workload along with the visibility of their performance results and are likely to disrupt the organization's power structure. Finally, most case study work finds that the development, implementation, use, and maintenance of CPM systems are very costly and time consuming, which generates additional conflicts and tensions (Ahn, 2001; Butler et al., 1997; Papalexandris et al., 2004). However, a recent study conducted by Cruz et al. (2011) contradicts previous work as they find that the use of a CPM system enhances the visibility and comparability of the performance of globally disperse sub-units while helping managers save time, especially in the process of analysing and monitoring organizational performance.

As a result, there is little consensus in the literature regarding the impact of CPM systems on conflicts and tension. Research suggests that the development of CPM systems brings about additional costs in terms of time and money due to the resources needed for defining and selecting performance measures, involving employees, and collecting performance data. Some organizations find that the use of the CPM system covers the high cost of developing it, as the system makes the process of analysing and monitoring performance more efficient. Other organizations, however, face more conflicts when using the CPM system due to issues 
associated with the higher visibility of performance, increased workload, and shifts in the power structure. Thus, the extent to which CPM systems help or hinder conflicts and tensions within organizations remains unresolved. Therefore, it is critical to identify those contingencies that help organizations benefit from CPM systems and to conduct longitudinal cost-benefit analyses to better understand the extent to which CPM systems are constructive or destructive.

INSERT TABLE 3

\subsection{Consequences for organizational capabilities}

The literature has investigated the impact of CPM systems on organizational capabilities in terms of strategy processes, communication, strategic capabilities, managerial practices, and corporate control (see Table 4). Each of these consequences is now reviewed in turn.

\subsubsection{Strategy processes: alignment, development, implementation, and review}

CPM systems have been found to positively influence the organization's strategy processes. Researchers find that CPM systems are effective mechanisms for (a) engaging managers in the strategy formulation and review processes, (b) enabling the strategy to be implemented as it facilitates the translation of strategy into operational terms, (c) encouraging managers to embrace the organization's strategy as a continuous process rather than a one-off exercise, and (d) improving strategic alignment, i.e., helping organizations align their actions in pursuit of their strategic objectives (Ahn, 2001; Chenhall, 2005; Cruz et al., 2011; De Geuser et al., 2009; Dossi and Patelli, 2010; Gimbert et al., 2010; Jazayeri and Scapens, 2008; Kolehmainen, 2010; Lillis, 2002; Malina and Selto, 2001; Marginson, 2002; Sandstrom 
and Toivanen, 2002). Nevertheless, the extent to which CPM systems are able to influence an organization's strategy processes is shaped by the cognitive limitations of managers (Ahn, 2001), alongside the way in which the system is designed, developed, and used (Gimbert et al., 2010; Lillis, 2002; Malina and Selto, 2001; Moon and Fitzgerald, 1996). Thus, CPM systems positively affect strategy processes, but the degree of this effect is subject to the CPM system's specific characteristics.

\subsubsection{Communication}

There is strong agreement on the impact of CPM systems on communication processes. This effect has been examined only through qualitative research studies. For instance, case studies conducted by Ahn (2001), Butler et al. (1997), Godener and Soderquist (2004), McAdam and Bailie (2002), Papalexandris et al. (2004), Tuomela (2005), and Sandstrom and Toivanen (2002) highlight the beneficial effects of CPM systems on communication processes at all levels of the organization. Only the work carried out by Malina and Selto (2001) finds, contrary to the researchers' expectations, that the CPM system studied in their case company was actually an ineffective communication device. In this particular company the CPM system was used for one-way reporting, which created conflicts and tension among managers and employees. The performance measures and benchmarks included in the system were imposed - without involving the employees in the process - and used for control and evaluation purposes. This communication approach generated distrust, dissatisfaction, and demotivation. In conclusion, it can be argued from looking at the evidence that CPM has a direct effect on communication, but its designers and users must emphasize the importance of generating a system supported by two-way communications to encourage knowledge-sharing, generate trust, and avoid resistance. 


\subsubsection{Strategic capabilities}

Some researchers have directly investigated the impact of CPM systems on a set of organizational strategic capabilities. Most of these researchers adopt Simon's levers of control framework (1995) and use a resource-based view approach (Barney, 2001) sometimes explicitly, other times implicitly. These researchers argue that CPM systems influence the strategic capabilities of organizations (specific abilities, processes, or competences that help the firm gain competitive advantage) through the routines they stimulate.

The most researched organizational capabilities are innovation and organizational learning. Regarding the impact of CPM systems on innovation, Cruz et al. (2011) find that the reorganization of a global CPM system fostered innovative practices (i.e., new ideas, products and ways of working). Marginson (2002) finds that the interactive use of a CPM system can enhance the development of new ideas and initiatives within a firm, improving innovation. The work of Bisbe and Otley (2004) further reviews the impact of CPM systems on innovation and finds that the interactive use of CPM systems favours innovation only in firms with low levels of innovation, whilst it actually mitigates against innovation in firms with high levels of innovation. Regarding the impact of CPM systems on organizational learning, the studies of Johnston et al. (2002), Godener and Soderquist (2004), Ahn (2001), and Chenhall (2005) suggest that when the focus of CPM systems is on action and improvement rather than on reporting and control, these systems are effective mechanisms for facilitating organizational learning that supports growth and development at all levels.

These findings are shared by Henri's (2006b) work. Specifically, Henri shows that the interactive use of CPM systems fosters organizational capabilities not only in terms of innovativeness and organizational learning but also in terms of entrepreneurship and market 
orientation. It does so by focusing organizational attention on strategic priorities and stimulating dialogue. Henri also finds that the diagnostic use of CPM systems weakens these capabilities. Thus, he asserts, the key is to balance the dynamic tension between these two CPM uses. Mundy (2010) extends Henri's work and suggests that the ability of organizations to balance the controlling (i.e., diagnostic) and the enabling or learning (i.e., interactive) uses of CPM systems constitutes a unique capability in its own right. Grafton et al. (2010) go a step further, showing that the use of CPM systems for feedback and feed-forward control in performance evaluation schemes (i.e., CPM type C system) affects the exploitation of existing capabilities and the search for and identification of new capabilities.

Based on the insights from the above studies, it can be argued that the appropriate balance between the diagnostic and the interactive uses of CPM systems can encourage the utilization and development of strategic firm capabilities such as organizational learning, entrepreneurship, and market orientation. The impact of CPM on innovation remains unclear, necessitating further research.

\subsubsection{Management practices}

The literature also explores the consequences of CPM on management practices. Using case study research, Ahn (2001) suggests that CPM systems are effective management devices as they integrate key management processes such as strategy development, communication, translation of strategy into operational terms, strategic feedback, and learning. Wouters and Wilderom (2008) and many others (e.g., Johnston et al., 2002; Malina and Selto, 2001; Papalexandris et al., 2004) point out that CPM systems may not always be effective management mechanisms. According to Wouters and Wilderom (2008), to be effective - or enabling rather than coercive - CPM systems must be developed and implemented building on employees' professionalism (in terms of their orientation toward 
learning for the purpose of improving work practices). Such systems should also acknowledge the organization's previous experience (existing skills, practices, and knowhow of involved employees), allowing experimentation with measures (i.e., testing, reviewing, refining) and encouraging transparency (through the participation and involvement of employees). Furthermore, Ukko et al. (2007) find that the impact of CPM systems on management practices highly depends on the maturity of the system, the organization's culture, the way the system is used, and the characteristics of the system's users (e.g., education, work experience). Thus, there is a relationship between CPM systems and management practices, but the positive or negative nature of this relationship is uncertain as there are a number of moderating factors.

\subsubsection{Corporate control}

Three studies look at the impact of CPM systems on corporate control. These are the studies conducted by Cruz et al. (2011), Dossi and Patelli (2010), and Kraus and Lind (2010). Cruz et al.'s (2011) case study finds that CPM systems enhance the visibility and comparability of the performance of sub-units, providing better coordination and control. Dossi and Patelli's (2010) survey finds that CPM systems can facilitate corporate control of subsidiaries, as the system strengthens strategic alignment and encourages dialogue between headquarters and subsidiaries, specifically through the use of non-financial performance indicators. The case study work of Kraus and Lind (2010) challenges the results of previous research. They find that the use of CPM systems at the corporate level has little impact on corporate control of international business units. Their evidence suggests that organizations are using CPM systems, but at the top level control is still exerted by focusing only on financial performance information because of top management's need for simplicity and internal comparability, and because of capital market pressures. In our view, this contradictory evidence deserves further attention, and further research in this area is highly 
encouraged. We speculate that contextual factors (e.g., environmental uncertainty and organizational culture) might play an important role in explaining these different findings.

\section{INSERT TABLE 4}

\subsection{Consequences for performance}

CPM systems have been found to influence performance at all levels of the organization (see Table 5). The following sub-sections describe these phenomena.

\subsubsection{Organizational and business unit performance}

The researchers that have investigated the impact of CPM systems on firm performance have operationalized performance in different ways. We have classified these into two groups: reported performance and perceived performance. Reported performance includes both financial (e.g., accounting performance, market performance) and non-financial performance (e.g., customer satisfaction) mainly based on the companies' annual reports. Perceived performance includes both financial and non-financial performance based on the research participants' perceptions of firm performance (e.g., perception of aspects such as performance outcomes, performance improvement, strategic goals achievement, and customer performance). The results of these two bodies of research are quite diverse, as described below.

The impact of CPM systems on reported performance is unclear, as the results of this body of literature are inconclusive. In terms of financial performance, one set of studies finds a positive effect of CPM systems on accounting performance (Banker et al., 2000; Crabtree and DeBusk, 2008; Cruz et al., 2011; Davis and Albright, 2004; Ittner and Larcker, 1998), 
stock market performance (Crabtree and DeBusk, 2008; HassabElnaby et al., 2005; Ittner, Larcker, and Randall, 2003; Said et al., 2003), and customer performance and other nonfinancial performance (Banker et al., 2000; Cruz et al., 2011; Hyvonen, 2007). A second set of studies finds no relationship - or a very weak relationship - between CPM systems and performance (HassabElnaby et al., 2005; Ittner, Larcker, and Randall, 2003; Said et al., 2003). Finally, a third set of studies finds mixed results (Braam and Nijssen, 2004; Griffith and Neely, 2009; Ittner and Larcker, 1997; Kihn, 2007).

As per the impact of CPM systems on managers' perception of the firm's financial and non-financial performance, the results are also inconsistent. Quantitative studies tend to find that CPM systems positively affect the firm's financial and non-financial performance according to the perceptions of managers (Chenhall, 2005; Chenhall and Langfield-Smith, 1998; De Geuser et al., 2009; Evans, 2004; Grafton et al., 2010; Henri, 2006b; Hoque, 2004; Hoque and James, 2000; Hyvonen, 2007; Lee and Yang, 2010; Van der Stede et al., 2006; De Waal et al., 2009), with the exception of the work of Braam and Nijssen (2004), which shows mixed effects, and Perera et al. (1997), which presents no effect. The impact of CPM systems on perceptions of a firm's financial and non-financial performance and on performance improvement in general is not always found to be positive in qualitative studies, as it is highly dependent on the way the CPM system is developed and used (Godener and Soderquist, 2004; Jazayeri and Scapens, 2008; Johnston et al., 2002; McAdam and Bailie, 2002; Malina and Selto, 2001; Papalexandris et al., 2004; Ukko et al., 2007).

The growing consensus in the literature seems to be that CPM systems do not automatically improve firm performance. Evidence suggests that it is the way these systems are designed, developed, and, more importantly, used that brings about performance improvements (e.g., Braam and Nijssen, 2004; Griffith and Neely, 2009; Ittner and Larcker, 1997; Henri, 2006a). Furthermore, a number of internal and external factors mediate or 
moderate the relationship between CPM systems and firm performance. The mediating factors have already been described in the previous sections. The moderating factors, which were not included earlier, are now presented.

In particular, researchers have investigated the moderating impact of the following: strategic orientation (Chenhall and Langfield-Smith, 1998; Ittner, Larcker, and Randall, 2003; Perera et al., 1997; Van der Stede et al., 2006), organizational structure and competition (Lee and Yang, 2010), perceived environmental change (Kihn, 2007) and environmental uncertainty (Hoque, 2004), organizational culture and management style (Bititci et al., 2006), and quality of information systems (Hyvonen, 2007). Some contingencies have not been found to influence the CPM-performance relationship, e.g., market position, product life cycle, and organizational size (Hoque and James, 2000). However, the effect of many contextual factors remains under-researched. Future research focusing on the circumstances under which we would expect to find positive and negative consequences of CPM systems would therefore be very beneficial.

\subsubsection{Team performance}

Only two studies explore the consequences of CPM systems on team performance. Scott and Tiessen (1999) report that the use of CPM improves the performance of teams. They find that performance results are enhanced when i) the team members participate in the setting of performance targets, and ii) team work is encouraged when team measures are a significant component of the individual's incentive compensation. The work of Davila (2000) focuses on project teams and shows that project performance in product development contexts improves when CPM systems are used, even though this positive impact is moderated by product uncertainty and product development strategy. Thus, based on the limited evidence available, we find that team performance improves, but the extent of the improvement is subject to the 
way the CPM system is designed and developed as well as other contextual factors (strategy alignment and degree of uncertainty). Further work in this area is needed, taking into consideration the importance of teams in the work place.

\subsubsection{Managerial performance}

There is now a growing body of research exploring the impact of CPM systems on managerial performance. This research emphasizes the importance of cognitive and motivational mechanisms for understanding how CPM affects individual results. The work in this area shows that CPM systems indirectly affect the performance of managers by reducing the manager's role ambiguity (Burney and Widener, 2007) as well as goal conflict (Cheng et al., 2007); by enhancing the psychological empowerment, goal clarity, and learning of managers (Hall, 2008, 2010); and by encouraging organizational citizenship (Burney et al., 2009). Future research in this area could further explore the relationship between CPM systems and managerial performance by looking at specific moderating effects, such as individual differences in knowledge (e.g., experience, education) and cognitive styles or ways of thinking. Griffith and Neely (2009) and Hall (2010) have already started to explore the influence of managerial experience on the use of CPM systems (even though they have not linked it to managerial performance directly). They find contradicting effects. Hall (2010) finds that short-tenure managers respond better to CPM systems, whilst Griffith and Neely (2009) find that those with long-tenure respond better to CPM systems. This inconsistency suggests the need for further research.

\subsubsection{Inter-firm performance}

The impact of CPM systems on inter-firm performance has received little attention in the literature. Only Cousins et al. (2008) and Mahama (2006) have explored this phenomenon. They both look at the supply relationships, finding that CPM systems enhance perceived 
inter-firm financial and non-financial performance indirectly by improving cooperation and socialization among the firms. This finding is encouraging, but more research in this area is required especially given the importance of buyer-supplier relationships in our current business environment.

\section{INSERT TABLES 5}

\section{$5.4 \quad$ Theories about the effects of CPM}

Proponents of CPM systems often promote the idea that CPM systems facilitate the implementation of the organization's business strategy, and by doing so improve overall organizational performance. This basic idea explains what CPM systems are supposed to do, but it fails to explain how. Although a number of theories have been used in the literature to explain how CPM systems affect performance and other intermediate factors, we will only focus on those that have been used in more than three of our selected studies. Table A.1 (Appendix) summarizes the different theories adopted by the papers reviewed. The theories are agency theory, contingency theory, resource-based view theory, cognitive and information processing theories, goal-setting theory, equity theory, and procedural and distributive justice theory. We now describe each of these theories and how the literature reviewed has used them.

\subsubsection{Agency theory}

Agency theory (Eisenhardt, 1989; Feltham and Xie, 1994; Jensen and Meckling, 1976; Jensen and Murphy, 1990) has been adopted mainly to elucidate two phenomena. Firstly, it has been used to explain how multi-criteria performance measures enhance organizational 
performance by helping to reduce the information asymmetry that exists between agents (e.g., managers) and principals (e.g., shareholders) (Dossi and Patelli, 2010; HassabElnaby et al., 2005; Said et al., 2003; Van der Stede et al., 2006). Secondly, agency-based research has been proposed to explain why the use of performance measures for individual performance evaluation and compensation is required in order to increase agents' motivation and focus on principals' goals (Banker et al., 2000; Burney and Widener, 2007; Griffith and Neely, 2009; Ittner, Larcker, and Meyer, 2003; Kihn, 2007; Moers, 2005). Agency theory tends to be used in combination with other theories such as contingency theory (e.g., Kihn, 2007) or theories from psychology (e.g., Decoene and Bruggeman, 2006; Malina and Selto, 2001).

\subsubsection{Contingency theory}

The contingency theory of organizations predicts that the relationship between an organization's characteristics, such as its performance measurement system, and organizational performance depends upon specific contingencies (Donaldson, 2001; Hayes, 1977; Otley, 1980). The key premise in this type of research is that performance measurement systems cannot be universally appropriate. Each organization needs to design its own system according to its circumstances to avoid loss of performance. In the literature, this theoretical approach has been adopted to highlight specific contingencies that may affect the impact of CPM systems, such as strategic orientation (e.g., Ittner, Larcker, and Randall, 2003) or environmental uncertainty (e.g., Hoque, 2004).

\subsubsection{Resource-based view of the firm}

The resource-based view of the firm (Barney, 2001) has been adopted to explain the impact of CPM systems on organizational capabilities. The resource-based view of the firm conceptualizes firms as bundles of resources and suggests that firms need to find those resources that are valuable, rare, inimitable, and non-substitutable in order to gain 
competitive advantages. Organizational capabilities are the processes by which firms acquire or develop their resources (Day, 1994). These capabilities can be enhanced or created by the joint use of CPM systems for both diagnostic and interactive purposes (Bisbe and Otley, 2004; Grafton et al., 2010; Henri, 2006a; Marginson, 2002; Mundy, 2010; Tuomela, 2005). In particular, the joint use of CPM systems for diagnostic and interactive purposes is highlighted in Simons' levers of control framework, as it "generates dynamic tension between opportunistic innovation and predictable goal achievement that is essential for positive growth" (1995, p.153).

\subsubsection{Cognitive and information-processing theories}

The use of cognitive psychology and decision-making research is shared by the literature looking at the effects of CPM systems on organizational, team, or individual performance evaluation. Specifically, this body of research is rooted in the notion that individuals have limited cognitive capacity (Miller, 1956) and their actual decision-making processes are not perfectly rational (Simon, 1976). For this reason, when using CPM systems, managers may evaluate and interpret data in ways consistent with their preferences (Tayler, 2010), a pervasive tendency known as 'motivated reasoning' (Kunda, 1990); they may focus only on the common measures (normally the financial ones), discarding or not paying attention to the non-common measures (normally the non-financial ones) (Lipe and Salterio, 2000, 2002; Slovic and MacPhillamy, 1974); they may add additional information to the attribute being measured for allocating bonuses (Dilla and Steinbart, 2005; Roberts et al., 2004); or they may tend to use lenient and more compressed performance ratings (Moers, 2005). 


\subsubsection{Goal-setting theory}

Goal-setting theory proposes that the particular attributes of personal ${ }^{8}$ goals have an effect on performance; more explicitly, the use of specific and challenging goals produces greater performance effects than the use of 'do your best' goals (Locke and Latham, 1990). In the CPM literature, goal-setting theory premises and constructs tend to be used for justifying the importance of using 'technically valid' performance measures in CPM systems (e.g., Burney et al., 2009). The typical argument used is that specific and clear performance measures and targets, such as the ones included in CPM systems, are associated with reduced ambiguity or confusion about strategic direction, which positively affects goal commitment, behaviour, and, ultimately, performance (e.g., Burney and Widener, 2007; Lau and Sholihin, 2005; Webb, 2004). This argument is normally followed by a discussion of the contribution from fairness and justice theory.

\subsubsection{Equity, distributive, and procedural justice theories}

Equity theory (Adams, 1965) suggests that individuals have their own beliefs about what is a fair reward for their contribution at work. Individuals compare their contributions and rewards with the contributions and rewards of others. If they perceive inequities, they will be motivated to seek justice (e.g., exerting dysfunctional behaviours, leaving the organization). Equity theory is highly related to justice theories. In particular, theorists distinguish between conceptualizations of justice that focus on content (the fairness of the ends received as stated by distributive justice) and on process (the fairness of the means used to achieve those ends as proposed by procedural justice) (Greenberg, 1990). Equity and justice theories have been adopted to explain why CPM systems can bring about perceptions of subjectivity that may

\footnotetext{
${ }^{8}$ It is important to note here that goal-setting theory mainly refers to the goals chosen by individuals, which may or may not be the same as the goals assigned by the organization (cf. Bonner and Sprinkle, 2002).
} 
negatively influence the effectiveness of the system. When individuals perceive that their performance evaluation is not based on a fair process (sometimes due to the ambiguity or inconsistency of the measures), they will behave accordingly and will be dissatisfied with the CPM system (e.g., Ittner, Larcker, and Meyer, 2003). Besides, when the notion of fairness and justice is taken into consideration during the system design, implementation, and use processes, the likelihood of success is higher (e.g., Burney et al., 2009).

\section{Discussion and conclusions}

The purpose of this paper is to contribute to a more complete understanding of the actual consequences of CPM systems. The evidence from our review of 76 empirical studies suggests that CPM systems significantly affect people's behaviour, organizational capabilities, and performance. More specifically, the data support the claim that CPM systems play a key role in strategy, communication, and management processes, generating organizational capabilities that enable the organization to excel (e.g., Eccles, 1991; Ittner and Larcker, 1998; Kaplan and Norton, 1996, 2001; Melnyk et al., 2004). CPM systems facilitate the development, implementation, and review of business strategies by focusing people's decisions and actions on strategic goals and by encouraging a continuous dialogue about strategic endeavours. CPM systems affect communication processes by requiring and providing relevant information that influence how people think, act, and interact. CPM systems influence organizational routines and management practices by changing the way leaders behave. All of these effects have a subsequent impact on performance at all levels.

The evidence reviewed also supports the claim that the extent to which a CPM system is able to positively influence people's behaviour, organizational capabilities, and, ultimately, performance is directly related to the way the system is designed, developed, and used, and to 
how well it fits the context in which it operates (e.g., Otley, 1999; Neely, 2005; FrancoSantos and Bourne, 2005). Regarding CPM systems design, researchers agree that to be effective these systems must comprise performance measures and targets that have high strategic alignment, controllability, timeliness, and technical validity (especially when used for compensation purposes). They should also state how the performance measures are interrelated using cause-and-effect relationships. Regarding CPM systems development, there is consensus on the importance of adopting a fair, transparent, and consultative process where people feel empowered and involved. CPM systems development should be iterative and incremental to allow continuous improvements. Regarding its use, there is agreement about the importance of finding a balance between diagnostic and interactive uses, and between informational and motivational uses of CPM systems, even though the literature provides little guidance on how to achieve this balance. Finally, the data suggest that the effectiveness of CPM systems is moderated by internal contingencies such as the employees' experience or the organization's strategic orientation, structure, information systems, culture, and management style, along with external contingencies such as competition or the degree of environmental uncertainty in which the organization operates.

On the less positive side, the evidence suggests that CPM systems in some cases may be time-consuming exercises that can increase costs and workloads, and generate internal tensions. CPM systems can also bring about judgement biases and perceptions of unfairness or subjectivity when they are used for performance evaluation and compensation purposes. In the last decade, the judgement biases produced by CPM systems have received considerable attention from researchers, and many tools and ideas have been proposed to rectify these biases. There is, however, a gap in our knowledge about the impact of CPM systems on costs, workloads, tensions, and subjectivity. We believe that these issues require further 
investigation as they may have a significant influence on the long-term consequences of CPM systems, as suggested by the work of Ittner, Larcker, and Meyer (2003).

When looking at the theories that have informed this area of research, we find, in the main, that six well-known theories have been adopted. These are agency theory, contingency theory, goal-setting theory, equity theory, resource-based view of the firm, and cognitivebased psychology research. Based on this finding, it can be argued that the consequences of CPM systems might be best explained by adopting a meta-theory approach, as has been proposed in other complex fields (e.g., Mauldin and Ruchala, 1999; Tsoukas, 1994). A metatheory approach will help provide an understanding of what theories explain specific CPM system effects and when they do it. It is important to highlight here that a third of the studies reviewed had no explicit theoretical underpinning, which suggests that our knowledge in this area is still at the modelling stage. Phenomena are being described, but explanations of why effects happen are not yet provided. The remaining studies use existing economic, psychology, and sociology theories for moving from the modelling stage to the theory stage.

Our findings have a number of implications for researchers interested in the area of CPM. Two research guidelines and several areas for further research emerge from our review. Regarding the research guidelines, we believe that future studies should clearly specify the CPM features being investigated along with the level at which they are examined in order to avoid confusion and increase comparability. We propose and validate a classification of CPM systems that was useful for us in our attempt to compare and extract insights from the literature. Feedback and extensions of this classification would be more than welcome. We also believe that the use of a contingent approach is highly recommended in this particular area of research, as we suspect that many of the inconsistencies found in the literature could be explained by looking at the context where the studies took place. 
As for the new areas for further research, we emphasize the following. Firstly, this review highlights the idea that it is not only the CPM system that matters but also the capability of managers and employees to respond to it. We still know little about the extent to which individual characteristics affect the impact of CPM systems. Some work has already been conducted in this area (e.g., Hall, 2008, 2010; Burney and Widener, 2007), but more would be welcome. Studies could examine the effect of managers' cognitive biases such as cognitive dissonance (Festinger, 1957), hindsight bias (Fischhoff and Beyth, 1975), or black swan bias (Taleb, 2005), which may shed some light into why many of the current CPM systems, despite their claimed positive effects, failed to predict the current financial crisis. Studies could also look at the effects of managers' experience, age, gender, skills, or abilities, as contradicting evidence has already been found (Hall, 2010; Griffith and Neely, 2009) and this needs clarification.

Secondly, new research could further investigate the impact of CPM systems on innovation, as this area remains unclear. As found in our review, Bisbe and Otley (2004) find no effect of CPM systems on innovation, whilst Henri (2006b) finds a positive effect. Why is this the case? Is there any missing variable that we should be considering in this relationship? Further research in this area could benefit from current work taking place in the fields of operations and corporate entrepreneurship (e.g., Goodale et al., 2011).

Thirdly, the use of performance measures for determining monetary rewards also deserves further attention, as many of the potential CPM system issues tend to be reinforced when the measures are linked to pay. For instance, Webb (2004) suggests that there is no need for the non-financial performance to be linked to pay (only the financial measures) if the cause-and-effect relationships among all the performance measures included in the CPM system are clear and strong. This idea, however, has not been fully explored in the literature. Further, measures are context and purpose specific, so measures that are designed for 
informational purposes (i.e., to evaluate firm performance at a corporate level) might not be adequate for motivational purposes (i.e., to decide monetary rewards at different levels of the organization). Research in this area could advance our understanding about why organizations struggle with the use of non-financial measures in incentive systems (Ittner, Larcker, and Meyer, 2003).

Fourthly, we still know little about how CPM systems are used in international organizations to facilitate strategy implementation. The studies of Cruz et al. (2011), Dossi and Patelli (2010), and Kraus and Lind (2010) are a good start in this area, but their inconsistent results deserve further attention. Moreover, in our review we found no evidence regarding the consequences of using CPM systems for assessing the performance of international teams (i.e., teams created from individuals working in different subsidiaries and in different countries).

Fifthly, our knowledge about the effects of CPM systems on change management is at an early stage. The work of Kolehmainen (2010) has stressed the positive impact of CPM systems on flexibility and adaptation, but previous work in the performance measurement literature (Euske et al., 1993) has suggested otherwise. To what extent do CPM systems support organizational change? How can CPM systems encourage flexibility and dynamism? These research questions remain unanswered and, especially in the current economic climate, require further attention.

Sixthly, previous research has looked at the effect of CPM systems on positive employee attitudes and behaviours. Further research could also explore whether CPM systems have any effect on negative employee attitudes or dysfunctional behaviours, as it has been suggested in related areas of research (e.g., Chwastiak, 2006; Jensen, 2003; Ordóñez et al., 2009). 
Finally, the impact of CPM systems on firm performance requires further investigation, as there is a lack of consistent evidence in this area. Researchers have argued that looking for a direct link between CPM systems and organizations' superior performance might be misleading due to the internal and external factors that play a role in economic performance evaluation (e.g., Lee and Yang, 2010). Insights from activity-based costing research (ABC) suggest that ABC may not, per se, add value, but merely be correlated with other organizational variables that are the true value drivers (Kennedy and Affleck-Graves, 2001). Taking this approach with CPM, we suggest that further CPM systems research should explore how this system interacts with other organizational variables, which, once again, supports the importance of using a contingency approach (e.g., Fisher, 1995) in this particular area of research.

Although the purpose of this literature review was to provide a guiding framework for further research rather than to generate any kind of practical prescriptions (Baldvinsdottir et al., 2010), our findings can also be useful for practitioners, especially those interested in adopting an evidence-based management approach (Rousseau, 2006). Understanding the consequences of CPM systems is an important topic for organizations because of the high investment that these systems require. From this review, three key implications for practitioners can be highlighted. First, practitioners can learn how important the processes of developing, implementing, using, and reviewing CPM systems are, and such practitioners can be informed of the tools that have been found useful in undertaking these processes. Second, they can learn how essential it is to pay attention to how people respond to these systems and to the different factors that affect their responses. Finally, practitioners can learn that the mere act of developing a CPM system is unlikely to enhance performance. In this paper, we find that numerous contingencies can influence the impact of these systems. Some of them are 
controllable, whilst others are not. Thus, practitioners must be aware of these contingencies and of the way they affect the effectiveness of CPM systems.

This study is not free of limitations. It is based on a literature review method that, despite being systematic and rigorous, might have missed some relevant work that (a) has been published in a journal outside our list of selected journals and has not been referenced by any of the work published in our list of selected journals; (b) has been published in areas other than accounting, operations, and strategy (e.g., information systems); (c) has been published in lower-ranked journals (e.g., Maiga and Jacobs, 2003); (d) has been published in a nonEnglish-language journal; or (e) refers to public sector organizations (e.g., Cavalluzzo and Ittner, 2004; Carmona and Gronlund, 2003; Johnston and Pongatichat, 2008; Moxham and Boaden, 2007; Umashev and Willet, 2008). Besides, when examining the work of qualitative studies we have relied on our own judgement and interpretation about the variables and relationships studied. This interpretation might not correspond entirely with the findings highlighted by the original authors of the studies.

\section{References}

ABS (2010). Academic journal quality guide. London: Association of Business Schools Publishing.

Adams, J. S. (1965). Inequity in social exchange. In Berkowitz, L. (ed.), Advances in experimental social psychology. New York: Academic Press.

Ahn, H. (2001). Applying the balanced scorecard concept: An experience report. Long Range Planning, 34 (4), 441-461.

Baldvinsdottir G., Mitchell F., \& Nørreklitc, H. (2010). 'Issues in the relationship between theory and practice in management accounting. Management Accounting Research, 21, pp. $79-82$. 
Banker, R. D., Chang, H. S., \& Pizzini, M. J. (2004). The balanced scorecard: Judgmental effects of performance measures linked to strategy. The Accounting Review, 79 (1), 1-23.

Banker, R. D., Potter, G., \& Srinivasan, D. (2000). An empirical investigation of an incentive plan that includes nonfinancial performance measures. The Accounting Review, 75 (1), Jan, 65-92.

Barney, J.B. (2001). Firm resources and sustained competitive advantage. Journal of Management, 17, 99-120.

Bisbe, J., \& Otley, D. (2004). The effects of the interactive use of management control systems on product innovation. Accounting Organizations and Society, 29 (8), 709-737.

Bititci, U. S., Carrie, A. S., \& Mcdevitt, L. (1997). Integrated performance measurement systems: A development guide. International Journal of Operations \& Production Management, 17 (5-6), 522-534.

Bititci, U. S., Mendibil, K., Nudurupati, S., Garengo, P., \& Turner, T. (2006). Dynamics of performance measurement and organizational culture. International Journal of Operations \& Production Management, 26 (11-12), 1325-1350.

Bonner, S., \& Sprinkle, G. (2002). The effects of monetary incentives on effort and task performance: Theories, evidence, and a framework for research', Accounting, Organizations and Society, 27, 303-345.

Braam, G. J. M., \& Nijssen, E. J. (2004). Performance effects of using the balanced scorecard: A note on the Dutch experience. Long Range Planning, 37 (4), 335-349.

Burney, L., \& Widener, S. K. (2007). Strategic performance measurement systems, jobrelevant information, and managerial behavioral responses-role stress and performance. Behavioral Research in Accounting, 19, 43-69.

Burney, L. L., Henle, C. A., \& Widener, S. K. (2009). A path model examining the relations 
among strategic performance measurement system characteristics, organizational justice, and extra- and in-role performance. Accounting, Organizations and Society, 34 (3/4), 305-321.

Butler, A., Letza, S. R., \& Neale, B. (1997). Linking the balanced scorecard to strategy. Long Range Planning, 30 (2), 242-253.

Cardinaels, E., \& Van Veen-Dirks, P. (2010). Financial versus non-financial information: The impact of information organization and presentation in a balanced scorecard. Accounting, Organizations and Society, 35, 565-578.

Carmona, S., \& Gronlund, A. (2003). Measures vs. actions: The balanced scorecard in Swedish law enforcement. International Journal of Operations \& Production Management, 23 (11-12), 1475-1496.

Cavalluzzo, K.S., \& Ittner, C.D. (2004). Implementing performance measurement innovations: Evidence from government. Accounting, Organizations and Society, 29 (3/4), 243.

Cheng, M. M., Luckett, P. F., \& Mahama, H. (2007). Effect of perceived conflict among multiple performance goals and goal difficulty on task performance. Accounting and Finance, 47 (2), 221-242.

Chenhall, R. H. (2005). Integrative strategic performance measurement systems, strategic alignment of manufacturing, learning and strategic outcomes: An exploratory study. Accounting Organizations and Society, 30 (5), 395-422.

Chenhall, R. H., \& Langfield-Smith, K. (1998). The relationship between strategic priorities, management techniques and management accounting: An empirical investigation using a systems approach. Accounting, Organizations and Society, 23 (3) Apr, 243-264.

Chwastiak, M. (2006). Rationality, performance measures and representations of reality: 
Planning, programming and budgeting and the Vietnam War. Critical Perspectives in Accounting, 17, 29-55.

Cousins, P. D., Lawson, B., \& Squire, B. (2008). Performance measurement in strategic buyer-supplier relationships: The mediating role of socialization mechanisms. International Journal of Operations \& Production Management, 28 (3), 238-258.

Crabtree, A. D., \& DeBusk, G. K. (2008). The effects of adopting the balanced scorecard on shareholder returns. Advances in Accounting, 24 (1), 8-15.

Cruz, I., Scapens, R. W., \& Major, M. (2011). The localisation of a global management control system. Accounting, Organizations and Society, 36 (7), 412-427.

Davila, A. (2000). An empirical study on the drivers of management control systems' design in new product development. Accounting, Organizations and Society, 25 (4-5) May-Jul, 383-409.

Davis, S., \& Albright, T. (2004). An investigation of the effect of balanced scorecard implementation on financial performance. Management Accounting Research, 15 (2), 135-153.

Day, G.S. (1994). The capabilities of market-driven organizations. Journal of Marketing, 38, $37-52$.

De Geuser, F., Mooraj, S., \& Oyon, D. (2009). Does the balanced scorecard add value? Empirical evidence on its effect on performance. European Accounting Review, 18 (1), 93-122.

De Waal, A., Kourtit, K., \& Nijkamp, P. (2009). The relationship between the level of completeness of a strategic performance management system and perceived advantages and disadvantages. International Journal of Operations \& Production Management, 29 (11-12), 1242-1265. 
Decoene, V., \& Bruggeman, W. (2006). Strategic alignment and middle-level managers' motivation in a balanced scorecard setting. International Journal of Operations \& Production Management, 26 (3-4), 429-448.

Dilla, W. N., \& Steinbart, P. J. (2005). Relative weighting of common and unique balanced scorecard measures by knowledgeable decision makers. Behavioral Research in Accounting, 17, 43-53.

Donaldson, L. (2001). The contingency theory of organizations. Thousand Oaks, CA: Sage Publications, Inc.

Dossi, A., \& Patelli, L. (2010). You learn from what you measure: Financial and nonfinancial performance measures in multinational companies. Long Range Planning, 43 (4), 498-526.

Eccles, R.G. (1991). The performance measurement manifesto. Harvard Business Review, Jan-Feb, 131-137.

Eccles, R. G., \& Pyburn, P. J. (1992). Creating a comprehensive system to measure performance. Management Accounting, Oct., 41-44.

Eisenhardt, K.M. (1989). Agency theory: An assessment and review. Academy of Management Review, 14 (1), 57-74.

Euske, K. J., Lebas, M. J., \& McNair, C. J. (1993). Performance management in an international setting. Management Accounting Research, 4 (4), 275-299.

Evans, J. R. (2004). An exploratory study of performance measurement systems and relationships with performance results. Journal of Operations Management, 22 (3), 219232.

Feltham, G. A., \& Xie, J. (1994). Performance-measure congruity and diversity in multitask principal-agent relations. The Accounting Review, 69 (3), 429-453. 
Festinger, L. (1957). A theory of cognitive dissonance. Stanford, CA: Stanford University Press.

Fischhoff, B., \& Beyth, R. (1975). I knew it would happen: Remembered probabilities of once-future things. Organizational Behavior and Human Performance, 13, 1-16.

Fisher, J. (1995). Contingency-based research on management control systems: Categorization by level of complexity. Journal of Accounting Literature, 14, 24-53.

Foster, G., \& Swenson, D. W. (1997). Measuring the success of ABC and its determinants. Journal of Management Accounting Research, 9, 109-141.

Franco-Santos, M., \& Bourne, M. (2005). An examination of the literature relating to issues affecting how companies manage through measures. Production Planning and Control, $16(4), 114-124$.

Franco-Santos, M., Kennerley, M., Micheli, P., Martinez, V., Mason, S., Marr, B., Gray, D., \& Neely, A. (2007). Towards a definition of a business performance measurement system. International Journal of Operations \& Production Management, 27, 784-801.

Gimbert, X., Bisbe, J., \& Mendoza, X. (2010). The role of performance measurement systems in strategy formulation processes. Long Range Planning, 43 (4), 477-497.

Godener, A., \& Soderquist, K. E. (2004). Use and impact of performance measurement results in R\&D: An exploratory study. R\&D Management, 34 (2), 191-219.

Goodale, J. C., Kuratko, D. F., Hornsby, J. S., \& Covin, J. G. (2011). Operations management and corporate entrepreneurship: The moderating effect of operations control on the antecedents of corporate entrepreneurial activity in relation to innovation performance. Journal of Operations Management, 29 (1-2), pp. 116-127.

Grafton, J., Lillis, A. M., \& Widener, S. K. (2010). The role of performance measurement and evaluation in building organizational capabilities and performance. Accounting 
Organizations and Society, 35 (7), 689-706.

Greenberg, J. (1990). Organizational justice: Yesterday, today, and tomorrow. Journal of Management, 16 (2), pp. 399-432.

Griffith, R., \& Neely, A. (2009). Performance pay and managerial experience in multitask teams: Evidence from within a firm. Journal of Labor Economics, 27 (1), 49-82.

Hall, M. (2008). The effect of comprehensive performance measurement systems on role clarity, psychological empowerment and managerial performance. Accounting Organizations and Society, 33 (2-3), 141-163.

Hall, M. (2010). Do comprehensive performance measurement systems help or hinder managers' mental model development? Management Accounting Research, doi:10.1016/j.mar.2010.10.002.

HassabElnaby, H. R., Said, A. A., \& Wier, B. (2005). The retention of nonfinancial performance measures in compensation contracts. Journal of Management Accounting Research,. 17, 23-42.

Hayes, D. C. (1977). The contingency theory of managerial accounting. The Accounting Review, 61 (1), 22-38.

Henri, J. F. (2006a). Organizational culture and performance measurement systems. Accounting Organizations and Society, 31 (1), 77-103.

Henri, J. F. (2006b). Management control systems and strategy: A resource-based perspective. Accounting Organizations and Society, 31 (6), 529-558.

Hoque, Z. (2004). A contingency model of the association between strategy, environmental uncertainty and performance measurement: Impact on organizational performance. International Business Review, 13 (4), 485-502.

Hoque, Z., \& James, W. (2000). Linking balanced scorecard measures to size and market 
factors: Impact on organizational performance. Journal of Management Accounting Research, 12, 1-17.

Hyvonen, J. (2007). Strategy, performance measurement techniques and information technology of the firm and their links to organizational performance. Management Accounting Research, 18 (3), 343-366.

Ittner, C. D., \& Larcker, D. F. (1997). Quality strategy, strategic control systems, and organizational performance. Accounting, Organizations and Society, 22 (3-4) Apr-May, 293-314.

Ittner, C. D., \& Larcker, D. F. (1998). Are nonfinancial measures leading indicators of financial performance? An analysis of customer satisfaction. Journal of Accounting Research, 36, 1-35.

Ittner, C.D. \& Larcker, D.F. (2001). Assessing empirical research in managerial accounting: A value-based management perspective, Journal of Accounting and Economics, 32, 349410.

Ittner, C. D. \& Larcker, D. F. (2003). Coming up short on nonfinancial performance measurement. Harvard Business Review, November, 88-95.

Ittner, C. D., Larcker, D. F., \& Meyer, M. W. (2003). Subjectivity and the weighting of performance measures: evidence from a balanced scorecard. The Accounting Review, 78 (3), 725-758.

Ittner, C. D., Larcker, D. F., \& Randall, T. (2003). Performance implications of strategic performance measurement in financial service firms. Accounting, Organizations and Society, 28 (7-8), 715-741.

Jazayeri, M., \& Scapens, R. W. (2008). The business values scorecard within BAE systems: The evolution of a performance measurement system. British Accounting Review, 40 
(1), 48-70.

Jensen, M. C. (2003). Paying people to lie: The truth about the budgeting process. European Financial Management, 9 (3), 379-406.

Jensen, M. C., \& Meckling, W. H. (1976). Theory of the firm: Managerial behaviour, agency cost and ownership structure. Journal of Financial Economics, 3, 305-360.

Jensen, M. C., \& Murphy, K. J. (1990). Performance pay and top-management incentives. Journal of Political Economy, 98 (21), 225-264.

Johnston, R., Brignall, S., \& Fitzgerald, L. (2002). Good enough performance measurement: A trade-off between activity and action. Journal of the Operational Research Society, 53 (3) Mar, 256-262.

Johnston, R., \& Pongatichat, P. (2008). Managing the tension between performance measurement and strategy: Coping strategies. International Journal of Operations \& Production Management, 28 (10), 941-967.

Kaplan, R. S., \& and Norton, D. P. (1992). The balanced scorecard - Measures that drive performance. Harvard Business Review, 70 (1) Jan-Feb, 71-79.

Kaplan, R. S., \& Norton, D. P. (1996). The balanced scorecard - Translating strategy into action. Boston, Mass: Harvard Business School Press.

Kaplan, R. S., \& Norton, D. P. (2000). Having trouble with your strategy? Then map it. Harvard Business Review, Sept-Oct., 167-176.

Kaplan, R. S., \& Norton, D. P. (2001). The strategy-focused organization: How balanced scorecard companies thrive in the new business environment. Boston, MA: Harvard Business School Press.

Kaplan, S. E., \& Wisner, P. S. (2009). The judgmental effects of management communications and a fifth balanced scorecard category on performance evaluation. 
Behavioral Research in Accounting, 21 (2), 37-56.

Kennedy, T., \& Affleck-Graves, J. (2001). The impact of activity-based costing techniques on firm performance. Journal of Management Accounting Research, 13, 19-45.

Kihn, L.-A. (2007). Financial consequences in foreign subsidiary manager performance evaluations. European Accounting Review, 16 (3), 531-554.

Kolehmainen, K. (2010). Dynamic strategic performance measurement systems: Balancing empowerment and alignment. Long Range Planning, 43 (4), 527-554.

Kraus, K., \& Lind, J. (2010). The impact of the corporate balanced scorecard on corporate control - A research note. Management Accounting Research, 21, 265-277.

Kunda, Z. (1990). The case for motivated reasoning. Psychological Bulletin, 108 (3), 480498.

Lau, C. M., \& Sholihin, M. (2005). Financial and nonfinancial performance measures: How do they affect job satisfaction? British Accounting Review, 37 (4), 389-413.

Lee \& Yang (2010). Organization structure, competition and performance measurement systems and their joint effects on performance. Management Accounting Research, doi:10.1016/j.mar.2010.10.003.

Libby, T., Salterio, S. E., \& Webb, A. (2004). The balanced scorecard: The effects of assurance and process accountability on managerial judgment. The Accounting Review, $79(4), 1075-1094$.

Liedtka, S., Church, B. K., \& Ray, M. (2008). Performance variability, ambiguity, intolerance, and balanced scorecard-based performance assessments. Behavioral Research in Accounting, 20 (2), 73-88.

Lillis, A. M. (2002). Managing multiple dimensions of manufacturing performance - An exploratory study. Accounting, Organizations and Society, 27 (6) Aug, 497. 
Lingle, J. H., \& Schiemann, W. A. (1996). From balanced scorecard to strategic gauges: Is measurement worth it?' Management Review, 85, 56-62.

Lipe, M. G., \& Salterio, S. E. (2000). The balanced scorecard: Judgmental effects of common and unique performance measures. The Accounting Review, 75 (3), 283-298.

Lipe, M. G., \& Salterio, S. E. (2002). A note on the judgmental effects of the balanced scorecard's information organization. Accounting, Organizations and Society, 27 (6) Aug, 531-540.

Locke, E., \& Latham, G. (1990). A theory of goal setting and task performance. Englewood Cliffs, N.J.: Prentice Hall.

Luft, J., \& Shields, M. (2003). Mapping management accounting: Graphics and guidelines for theory-consistent empirical research. Accounting, Organizations and Society, 28, 169249.

Mahama, H. (2006). Management control systems, cooperation and performance in strategic supply relationships: A survey in the mines. Management Accounting Research, 17 (3), 315-339.

Maiga, A. S., \& Jacobs, F. A. (2003). Balanced scorecard, activity-based costing and company performance: An empirical analysis. Journal of Managerial Issues, 15 (3), 283-301.

Malina, M. A., \& Selto, F. H. (2001). Communicating and controlling strategy: An empirical study of the effectiveness of the balanced scorecard. Journal of Management Accounting Research, 13, 47.

Malmi, T. (2001). Balanced scorecards in Finnish companies: A research note. Management Accounting Research, 12, 207-220.

Marginson, D. E. W. (2002). Management control systems and their effects on strategy 
formation at middle-management levels: Evidence from a UK organization. Strategic Management Journal, 23 (11), 1019-1031.

Mauldin, E. G., \& Ruchala, L. V. (1999). Towards a meta-theory of accounting information systems. Accounting, Organizations and Society, 24 (4), 317-331.

McAdam, R., \& Bailie, B. (2002). Business performance measures and alignment impact on strategy - The role of business improvement models. International Journal of Operations \& Production Management, 22 (9-10), 972-996.

Melnyk, S. A., Stewart, D. M., \& Swink, M. (2004). Metrics and performance measurement in operations management: Dealing with the metrics maze. Journal of Operations Management, 22 (3), 209-217.

Miller, G. (1956). The magical number seven, plus or minus two: Some limits on our capacity for information processing, Psychological Review, March, 81-96.

Moers, F. (2005). Discretion and bias in performance evaluation: The impact of diversity and subjectivity. Accounting Organizations and Society, 30 (1), 67-80.

Moon, P., \& Fitzgerald, L. (1996). Delivering the goods at TNT: The role of the performance measurement system. Management Accounting Research, 7 (4), 431-457.

Moxham, C., \& Boaden, R. (2007). The impact of performance measurement in the voluntary sector. International Journal of Operations \& Production Management, 27 (8), 826-845.

Mundy, J. (2010). Creating dynamic tensions through a balanced use of management control systems. Accounting Organizations and Society, 35 (5), 499-523.

Neely, A. (2005). The evolution of performance measurement research - Developments in the last decade and a research agenda for the next. International Journal of Operations \& Production Management, 25 (12), 1264-1277.

Neely, A. D., Adams, C., \& Kennerley, M. (2002). The performance prism: The scorecard 
for measuring and managing business success. London, UK: Pearson Education Ltd.

Neely, A. D., Yaghi, B., \& Youell, N. (2008). Enterprise performance management: The global state of the art. Cranfield: Oracle and Cranfield School of Management publication.

Otley, D. (1999). Performance management: A framework for management control systems research. Management Accounting Research, 10 (4), 363-82.

Otley, D. T. (1980). The contingency theory of management accounting: Achievement and prognosis. Accounting, Organizations and Society, 5 (4), 413-428.

Ordóñez, L., Schweitzer, M. E., Galinsky, A. D., \& Bazerman, M. H. (2009). Goals gone wild: How goals systematically harm individuals and organizations. Academy of Management Perspectives, 23 (1), 6-16.

Papalexandris, A., Ioannou, G., \& Prastacos, G.P. (2004). Implementing the balanced scorecard in Greece: A software firm's experience. Long Range Planning, 37 (4), 351366.

Perera, S., Harrison, G., \& Poole, M. (1997). Customer-focused manufacturing strategy and the use of operations-based non-financial performance measures: A research note. Accounting, Organizations and Society, 22 (6), 557-572.

Rigby, D., \& Bilodeau, B. (2009). Management tools and trends. US: Bains and Co.

Roberts, M. L., Albright, T. L., \& Hibbets, A. R. (2004). Debiasing balanced scorecard evaluations. Behavioral Research in Accounting, 16, 75-88.

Rousseau, D. (2006). Is there such a thing as 'evidence based management'? Academy of Management Review, 31 (2), 256-269.

Saari, L. M., \& Judge, T. A. (2004). Employee attitudes and job satisfaction. Human Resource Management, 43 (4), 395-407. 
Said, A. A., HassabElnaby, H. R., \& Wier, B. (2003). An empirical investigation of the performance consequences of nonfinancial measures. Journal of Management Accounting Research, 15, 193-223.

Sandstrom, J., \& Toivanen, J. (2002). The problem of managing product development engineers: Can the balanced scorecard be an answer? International Journal of Production Economics, 78 (1), 79-90.

Schiff, A. D., \& Hoffman, L. R. (1996). An exploration of the use of financial and nonfinancial measures of performance by executives in a service organization. Behavioral Research in Accounting, 8, 134.

Scott, T. W., \& Tiessen, P. (1999). Performance measurement and managerial teams. Accounting, Organizations and Society, 24 (3), 263-285.

Shields, M. D. (1995). An empirical analysis of firms' implementation experiences with activity-based costing. Journal of Management Accounting Research, 7, 148-166.

Simon, H.A. (1976). Administrative behavior (3rd. ed. edition). New York: Free Press.

Simons, R. (1995). Levers of control: How managers use innovative control systems to drive strategic renewal. Boston, MA: Harvard Business School Press.

Slovic, P., \& MacPhillamy, D. (1974). Dimensional commensurability and cue utilization in comparative judgement. Organizational Behaviour and Human Performance, 11, 172194.

Speckbacher, G., Bischof, J., \& Pfeiffer, T. (2003). A descriptive analysis on the implementation of balanced scorecards in German-speaking countries. Management Accounting Research, 14 (4), 361-388.

Stangor, C. (2010). Research methods for the behavioural sciences. Belmont, CA: Wadsworth Cengage Learning. 
Taleb, N. (2005). The black swan: Why don't we learn that we don't learn? NY: Random House.

Tayler, W.B. (2010). The balanced scorecard as a strategy-evaluation tool: The effects of implementation involvement and a causal-chain focus. The Accounting Review, 85 (3), 1095-1117.

Tsoukas, H. (1994). What Is management? An outline of a metatheory. British Journal of Management, 5 (4), 289.

Tuomela, T. (2005). The interplay of different levers of control: A case study of introducing a new performance measurement system. Management Accounting Research, 16, 293-320.

Ukko, J., Tenhunen, J., \& Rantanen, H. (2007). Performance measurement impacts on management and leadership: Perspectives of management and employees. International Journal of Production Economics, 110 (1-2), 39-51.

Umashev, C., \& Willett, R. (2008). Challenges to implementing strategic performance measurement systems in multi-objective organizations: The case of a large local government authority. Abacus, 44 (4), 377-398.

Van der Stede, W. A., Chow, C. W., \& Lin, T. W. (2006). Strategy, choice of performance measures, and performance. Behavioral Research in Accounting, 18, 185-205.

Webb, R. A. (2004). Managers' commitment to the goals contained in a strategic performance measurement system. Contemporary Accounting Research, 21 (4), 925958.

Wiersma, E. (2009). For which purposes do managers use balanced scorecards? An empirical study. Management Accounting Research, 20, 239-251.

Wong-on-Wing, B., Guo, L., Li, W., \& Yang, D. (2007). Reducing conflict in balanced scorecard evaluations. Accounting Organizations and Society, 32 (4-5), 363-377. 
Wouters, M., \& Wilderom, C. (2008). Developing performance-measurement systems as enabling formalization: A longitudinal field study of a logistics department. Accounting Organizations and Society, 33 (4-5), 488-516. 


\section{Tables and Figures}

Table 1. Contemporary performance measurement types

\begin{tabular}{|c|c|c|c|c|}
\hline & CPM A & СРМ B & СРМ C & CPM D \\
\hline Components & $\begin{array}{l}\text { - Financial and } \\
\text { non-financial } \\
\text { performance } \\
\text { measures } \\
\text { implicitly or } \\
\text { explicitly linked } \\
\text { to strategy }\end{array}$ & $\begin{array}{l}\text { - Financial and non- } \\
\text { financial } \\
\text { performance } \\
\text { measures explicitly } \\
\text { linked to strategy } \\
\text { - With explicit cause- } \\
\text { and-effect } \\
\text { relationships among } \\
\text { measures }\end{array}$ & $\begin{array}{l}\text { - Financial and non- } \\
\text { financial performance } \\
\text { measures explicitly or } \\
\text { implicitly linked to } \\
\text { strategy }\end{array}$ & $\begin{array}{l}\text { - Financial and } \\
\text { non-financial } \\
\text { performance } \\
\text { measures } \\
\text { explicitly or } \\
\text { implicitly linked } \\
\text { to strategy }\end{array}$ \\
\hline Use/purpose & $\begin{array}{l}\text { - Inform decision- } \\
\text { making } \\
\text { - Evaluate } \\
\text { organizational } \\
\text { performance }\end{array}$ & $\begin{array}{l}\text { - Inform decision- } \\
\text { making } \\
\text { - Evaluate } \\
\text { organizational } \\
\text { performance }\end{array}$ & $\begin{array}{l}\text { - Inform decision- } \\
\text { making } \\
\text { - Evaluate } \\
\text { organizational and } \\
\text { managerial } \\
\text { performance (without } \\
\text { links to monetary } \\
\text { rewards) }\end{array}$ & $\begin{array}{l}\text { - Inform decision- } \\
\text { making } \\
\text { - Evaluate } \\
\text { organizational and } \\
\text { managerial } \\
\text { performance } \\
\text { - Influence } \\
\text { monetary rewards }\end{array}$ \\
\hline
\end{tabular}


Table 2. Number of studies classified according to CPM type and research method used

\begin{tabular}{|c|c|c|c|c|c|c|}
\hline & CPM A & CPM B & CPM C & CPM D & Mixed & Total \\
\hline Archival & $\cdot 1$ & & & - 4 & & 5 \\
\hline Survey & $\begin{array}{l}.9 \\
.2 \text { (LoC) } \\
.4 \text { (BSC) }\end{array}$ & - 4 & $\begin{array}{l}\text {. } 1 \\
\text {. } 2 \text { (BSC) }\end{array}$ & - 2 & $\begin{aligned} & 1 \text { (CPM A, B \& D) } \\
: & 1 \text { (BSC - CPM A, B \& D) } \\
: & 1 \text { (BSC - CPM A \& B) }\end{aligned}$ & 27 \\
\hline Experiment & & - 1 & $\begin{array}{l}\text { - } 9 \text { (BSC) } \\
\text { - } 1\end{array}$ & & - $2(\mathrm{BSC}-\mathrm{CPM}$ C \& D) & 13 \\
\hline Quasi-experiment & & - 1 (BSC) & & - 1 (BSC) & & 2 \\
\hline Case/field study & $\begin{array}{l}: 7 \\
: 1 \text { (LoC) } \\
.3 \text { (BSC) }\end{array}$ & - 3 (BSC) & - 1 & $\begin{array}{l}2 \\
: 3 \text { (BSC) }\end{array}$ & & 20 \\
\hline Mixed methods & $\begin{array}{l}\text { - } 1 \text { case study \& } \\
\text { action research } \\
\text { - } 1 \text { survey and } \\
\text { interviews }\end{array}$ & $\begin{array}{l}\text { - } 1 \text { (LoC) case } \\
\text { study \& action } \\
\text { research } \\
\text { - } 1 \text { (BSC) survey \& } \\
\text { archival }\end{array}$ & $\begin{array}{l}\text { - } 1 \text { (LoC) case } \\
\text { study \& archival } \\
\text { - } 1 \text { case study and } \\
\text { archival } \\
\text { - } 1 \text { survey \& } \\
\text { archival }\end{array}$ & $\begin{array}{l}\text { - } 1 \text { (BSC) archival } \\
\& \text { survey } \\
\text { - } 1 \text { survey and } \\
\text { interviews }\end{array}$ & & 9 \\
\hline Total & 29 & 11 & 17 & 14 & 5 & 76 \\
\hline
\end{tabular}


Table 3. Consequences of CPM systems on people's behaviour CPM system type A CPM system type B

Cooperation, coordination, and participation

Cooperation, coordination, and participation
- Cooperation

- Relationships among

headquarters and

subsidiaries

- $[+$, S] Dossi and Patelli (2010)

Socialization

- [+, CS] Cruz et al. (2011)

- [+, S] Cousins et al. (2008); [+, S Mahama (2006)

- Participation

- [+, CS] Butler et al. (1997)

- [+, CS] Papalexandris et al. (2004); [+,

- $[+$, CS $]$ Kolehmainen (2010)

- Relationships within and

CS] Sandstrom and Toivanen (2002)

- $[+$, CS] Papalexandris et al. (2004) [+, S] Wiersma (2009)

among departments

Motivation

Motivation

- [+, CS] Godener and Soderquist (2004)

- Influenced by participation [+, CS

(Godener and Soderquist, 2004)

- [+, CS] Papalexandris et al. (2004); [+,

CS] Sandstrom and Toivanen (2002)

[-, CS] Decoene and Bruggeman (2006);

[-, CS] Malina and Selto (2001)

Influenced by strategic alignment [+, CS

and the development and use of CPM [+,

CS] (Decoene and Bruggeman, 2006;

Malina and Selto, 2001), as well as by

CPM operating as an effective

communication tool $[+, \mathrm{CS}]$ (Malina and

- Psychological

- $[+$, S] Hall (2008)

Selto, 2001)

empowerment

- Mediated by role clarity [+, S] (Hall,

2008)

- Goal commitment

- $[+$, E] Webb (2004)

- Moderated by goal attractiveness [+, E]

and managers' self-efficacy $[+, E]$ (Webb, 2004)

\section{Citizenship behaviours}

- Organizational

citizenship behaviours

- [+, S] Burney et al. (2009)

- Mediated by perception

\section{Role understanding}

- Role conflict

- [-, S] Burney and Widener (2007)

- Moderated by the number of

measures/complexity [-, S] (Burney and

Widener, 2007)

- Goal conflict

- [+, S] Cheng et al. (2007)

- Moderated by the individual's perceived

goal difficulty [+, S] (Cheng et al., 2007) 


\begin{tabular}{|c|c|c|c|c|}
\hline & CPM system type A & CPM system type B & CPM system type $\mathrm{C}$ & CPM system type D \\
\hline - Role ambiguity & & $\begin{array}{l}\text { - }[-, \text { S] Burney and Widener (2007) } \\
\text { Moderated by experience [+, S] and the } \\
\text { coupling of the CPM system to evaluation } \\
\text { and compensation (i.e., CPM D) [-, S] } \\
\text { (Burney and Widener, 2007). } \\
\text { - Mediated by job relevant information [-, } \\
\text { S] (Burney and Widener, 2007) }\end{array}$ & & \\
\hline - Job relevant information & & $\begin{array}{l}\text { - }[+, \text { S] Burney and Widener (2007) } \\
\text { - Moderated by managerial experience [ } \\
\text { S] (Burney and Widener, 2007) }\end{array}$ & & \\
\hline - Role clarity & & - $[+$, S $]$ Hall $(2008)$ & & \\
\hline - Job satisfaction & & & $\begin{array}{l}\text { - }[+, \mathrm{S}] \text { Lau and Sholihin }(2005) \\
\text { Mediated by trust in supervisor }[+, \mathrm{S}] \text { and } \\
\text { perceived fairness [+, S] (Lau and } \\
\text { Sholihin, 2005) }\end{array}$ & \\
\hline \multicolumn{5}{|c|}{ Decision making, learning, and self-monitoring } \\
\hline $\begin{array}{l}\text { Managerial decision- } \\
\text { making } \\
\text { Managerial self- } \\
\text { monitoring } \\
\text { - Managerial learning }\end{array}$ & - [+, S] Grafton et al. (2010) & $\begin{array}{l}\text { - }[+, \text { S }] \text { Hall }(2010) ;[+, \text { CS }] \text { Tuomela } \\
\text { (2005) } \\
\text { - Moderated by size of business unit }[-, \text { S }] \\
\text { and managerial experience [-, S] (Hall, } \\
2010 \text { ) }\end{array}$ & $\begin{array}{l}\text { - }[+, \text { S }] \text { Wiersma }(2009) \\
\text { - }[+, \text { S }] \text { Wiersma }(2009)\end{array}$ & \\
\hline \multicolumn{5}{|l|}{ Leadership and culture } \\
\hline - Leadership & - [+, CS] Bititci et al. (2006) & & & $\begin{array}{l}\text { - [+, CS] Ukko et al. (2007) } \\
\text { - Influenced by organizational culture [+, } \\
\text { CS], managerial education level [+, CS], } \\
\text { managerial experience [+, CS], and the } \\
\text { maturity of the CPM system [+, CS] } \\
\text { (Ukko et al., 2007) }\end{array}$ \\
\hline - Organizational culture & - $[+$, CS] Bititci et al. (2006) & & & - $[+$, CS $]$ Jazayeri and Scapens (2008) \\
\hline \multicolumn{5}{|l|}{ Satisfaction } \\
\hline $\begin{array}{l}\text { Perceived satisfaction } \\
\text { with the CPM system }\end{array}$ & $\begin{array}{l}\text { - }[+, \text { S] Ittner, Larcker, and Randall, } \\
\quad(2003) ;[+, \text { CS }] \text { Malmi (2001) }\end{array}$ & & & $\begin{array}{l}\text { - }[+, \text { S] Speckbacher et al. (2003); [+, CS] } \\
\text { Jazayeri and Scapens (2008); [-, S] Ittner, } \\
\text { Larcker, and Meyer (2003) } \\
\text { - Influenced by the perceived subjectivity } \\
\text { in the system; Ittner, Larcker, and Meyer } \\
\text { (2003) }\end{array}$ \\
\hline \multicolumn{5}{|c|}{ Perceptions of subjectivity, justice, and trust } \\
\hline - Subjectivity & & & $\begin{array}{l}\text { - }[+, \text { CS] Kolehmainen (2010) (seen as a } \\
\text { positive outcome as it enhances } \\
\text { flexibility) }\end{array}$ & $\begin{array}{l}\text { - }[+, \text { A \& S] Ittner, Larcker, and Meyer } \\
\text { (2003) }\end{array}$ \\
\hline - Perceptions of trust & & & - $[+$, S $]$ Lau and Sholihin (2005) & \\
\hline - Perceptions of justice & & - $[+$, CS $]$ Papalexandris et al. (2004) & - $[+$, S] Lau and Sholihin (2005) & - $[+$, S] Burney et al. $(2009)$ \\
\hline
\end{tabular}


- [+, E] Lipe and Salterio (2000, 2002); [+, E] Libby et al. (2004); [+, E] Banker et al. (2004); [+, E] Cardinaels and Van VeenDirks (2010); [+, E] Dilla and Steinbart (2005); [+, E] Kaplan and Wisner (2009); $[+$, E] Liedtka et al. (2008); [+, E] Roberts $[+$, E] Liedka et al. (2008); [+, E] Robert et al. (2004), [+, E] Schirf and Holfment (1996), [+, E] Wong-on-Wing et al.

$(2007)$

- Moderated by the use of an assurance report [+, E] (Libby et al., 2004); the different BSC formats [+, E] (Cardinaels and Van Veen-Dirks, 2010; Kaplan and Wisner, 2009; Lipe and Salterio, 2000, 2002); the evaluator's level of ambiguity intolerance [+, E] (Liedtka et al., 2008); process accountability $[+, \mathrm{E}]$ (Libby et al. 2004); managers' knowledge about the BU strategy [+, E] (Band Keplan a Wisne, 2009; Wong-onKaplan and Wisner, 2009, Wong-onWing et al., 2007), managerial training and experience about the design and structure of the BSC [ + , E] (Dilla and Steinbart, 2005); level of performance judgement [+/-, E] (Schiff and Hoffman, 1996); and managerial role [+/-, E] (Wong-on-Wing et al., 2007)

- Strategic initiative evaluation bias

- Bonus allocation bias

\section{Conflicts and tensions} - Tension/conflict

- [+, CS] Marginson (2002)

- Influenced by poor communication

- [+, E] Tayler (2010)

- Moderated by the type of BSC format [+,

$E]$ and participation or involvement in the

selection of strategic initiatives [+, E]

(Tayler, 2010) lenient performance ratings and comprised performance rating
(Marginson, 2002)

- Time consuming

$$
\begin{aligned}
& \text { - }[+, \text { CS] Butle } \\
& \text { et al. (2011) }
\end{aligned}
$$

- $[+$, CS] Cruz et al. (2011)
- [+, CS] Papalexandris et al. (2004)

- [+, E] Dilla and Steinbart (2005); [+, E] Roberts et al. (2004)

- Moderated by managers' knowledge of the design and structure of the BSC $[+, \mathrm{E}]$ (Dilla and Steinbart, 2005)

[+, CS] Malina and Selto (2001)

Selto, 2001)

- $[+$, CS $]$ Ahn (2001); [+, CS

Papalexandris et al. (2004); [+, CS]

Tuomela (2005)

[-, CS] Tuomela (2005) 

- $[+$, CS $]$ Tuomela $(2005)$

Notes: The sign within [] refers to the type of impact found in the study: [+] refers to positive effects; [-] refers to negative effects; [+/-] refers to mixed effects; [--] refers to no effects found; [ $[$ refers to curvilinear effects. The abbreviations within [] refer to the research method used in the study: [CS] Case Study, [S] Survey, [A] Archival, [QE] Quasi-experiment, and [E] Experiment. 


\begin{tabular}{|c|c|c|c|c|}
\hline \multicolumn{5}{|c|}{ Strategy processes: alignment, development, implementation, and review } \\
\hline - Strategic alignment & $\begin{array}{l}\text { - [+, CS] Cruz et al. (2011); [+, S] Dossi } \\
\text { and Patelli (2010) }\end{array}$ & $\begin{array}{l}\text { [+, S] Chenhall (2005); }[+, \text { CS }] \text { Ahn } \\
(2001) ;[+, \text { CS }] \text { Sandstrom and Toivanen } \\
\text { (2002) } \\
\text { - Influenced by strategic orientation } \\
\text { (supplier, strategic/operational) }[+, \mathrm{S}] \\
\text { (Chenhall, 2005)] }\end{array}$ & - $[+$, CS] Kolehmainen (2010) & $\begin{array}{l}\text { - }[+, \text { CS] Jazayeri and Scapens (2008); [+, } \\
\text { CS] Malina and Selto (2001). } \\
\text { - Moderated by the CPM meeting the } \\
\text { characteristics of an effective system [+, } \\
\text { CS] (Malina and Selto, 2001) }\end{array}$ \\
\hline $\begin{array}{l}\text { - Strategy development/ } \\
\text { continuous process }\end{array}$ & $\begin{array}{l}\text { - }[+, \text { S] Gimbert et al. (2010); [+, CS }] \\
\text { Marginson (2002) }\end{array}$ & $\begin{array}{l}\text { - }[+, \text { CS }] \text { Tuomela }(2005) ;[+, \text { CS] Ahn } \\
\text { ( } 2001) \\
\text { - Influenced by environmental risk [-CS] } \\
\text { (Ahn, 2001) }\end{array}$ & & - [+, CS] Jazayeri and Scapens (2008) \\
\hline - Strategy implementation & $\begin{array}{l}\text { - }[+, \text { S] De Geuser et al. (2009); [+, CS] } \\
\text { Lillis (2002) } \\
\text { - Influenced by the use of loose controls } \\
\text { [+, CS] and technical integration of } \\
\text { performance measures [+/-, CS] (Lillis } \\
(2002)\end{array}$ & $\begin{array}{l}\text { - }[+, \text { CS }] \text { Ahn (2001) } \\
\text { - Influenced by managers' cognitive } \\
\text { limitations [-, CS] (Ahn, 2001) }\end{array}$ & & $\begin{array}{l}\text { - }[+, \text { CS] Moon and Fitzgerald (1996) } \\
\text { - Influenced by the way in which the CPM } \\
\text { has been developed and used [+/-, CS] } \\
\text { (Moon and Fitzgerald, 1996) }\end{array}$ \\
\hline \multicolumn{5}{|l|}{ Communication } \\
\hline - Communication & $\begin{array}{l}\text { - [+, CS] Butler et al. (1997); [+, CS] Cruz } \\
\text { et al. (2011) [+, CS]; Godener and } \\
\text { Soderquist (2004) }\end{array}$ & $\begin{array}{l}\text { - }[+, \text { CS }] \text { Ahn }(2001) ;[+, \text { CS }] \\
\text { Papalexandris et al. (2004), [+, CS }] \\
\text { Tuomela (2005); [+, CS }] \text { Sandstrom and } \\
\text { Toivanen }(2002)\end{array}$ & - $[+$, CS $]$ McAdam and Bailie (2002) & \\
\hline \multicolumn{5}{|l|}{ Strategic capabilities } \\
\hline - Entrepreneurship & $\begin{array}{l}\text { [+, S] Henri (2006b) } \\
\text { - Mediated by the interactive use of CPM } \\
\\
{[+, \text { S] (Henri, 2006b) }}\end{array}$ & & & \\
\hline - Innovativeness & $\begin{array}{l}\text { - }[+, \text { S] Henri (2006b); [+/-, S] Bisbe and } \\
\text { Otley (2004); [+, CS] Cruz et al. (2011); } \\
\text { [+, CS] Marginson (2002) } \\
\text { - Mediated by the interactive use of CPM } \\
\text { [+/-, S] (Bisbe and Otley, 2004) [+, S] } \\
\text { (Henri, 2006b) [+, CS] Marginson, 2002) }\end{array}$ & & & \\
\hline - Dynamic tension & $\begin{array}{l}\text { [+, S] Henri (2006b) } \\
\text { - Moderately by environmental uncertainty } \\
\text { [+, S] and organizational culture [+/-, S] } \\
\text { (Henri, 2006b) }\end{array}$ & & $\begin{array}{l}\text { - }[+, \text { CS] Mundy (2010) } \\
\text { - Mediated by establishing a balanced } \\
\text { between the interactive and diagnostic } \\
\text { use of CPM [+, CS] (Mundy, 2010) }\end{array}$ & \\
\hline - Market orientation & $\begin{array}{l}\text { [+, S] Henri (2006b) } \\
\text { - Mediated by the interactive use of CPM } \\
\\
{[+, \text { S] (Henri, 2006b) }}\end{array}$ & & & \\
\hline - Organizational learning & $\begin{array}{l}\text { - }[+, \text { S }] \text { Henri }(2006 \mathrm{~b}) ;[+/-, \text { CS }] \text { Johnston } \\
\text { et al. (2002) } \\
\text { - Mediated by the interactive use of CPM }\end{array}$ & $\begin{array}{l}\text { - }[+, \text { S ] Chenhall }(2005) ;[+, \mathrm{CS}] \text { Ahn } \\
\text { ( } 2001) \\
\text { - Influenced by strategic orientation }\end{array}$ & & \\
\hline
\end{tabular}


- Moderated by the way in which the CPM (Chenhall, 2005)

was developed and used [+/-, CS]

(Johnston et al., 2002; Godener and

Soderquist, 2004)

- Strategic capabilities

- [+, S] Grafton et al. (2010)

(exploiting old and

$$
\text { finding new) }
$$

\section{Management practices}

- Management practices

- [+, CS] Johnston et al. (2002); [+, CS

- Influenced by CPM system purpose,
Wouters and Wilderom (2008)

Papalexandris et al. (2004)

development, and use [+/-, CS] (Johnston CS] Papalexandris et al. (2004)

2008) 2002; Wouters and Wilderom,
- [+, CS] Ahn (2001); [+, CS

- [+, CS] Malina and Selto (2001); [+, CS

- Influenced by CPM system purpose

development, and use [+/-, CS] (Malina and Selto, 2001); organizational culture $[+, \mathrm{CS}]$, managerial education [+, CS], managerial work experience $[+, \mathrm{CS}]$, the maturity of the CPM system [+, CS]

(Ukko et al., 2007);

\section{Corporate control}

- Corporate contro

- [+, CS] Cruz et al. (2011); [--, CS] Kraus

and Lind (2010); [+, S] Dossi and Patelli

(2010)

- Influence by accountability $[+, \mathrm{CS}]($ Cruz

et al., 2011)

otes: The sign within [] refers to the type of impact found in the study: [+] refers to positive effects; [-] refers to negative effects; [+/-] refers to mixed effects; [--] refers to no effects found;

curvilinear effects. The abbreviations within [] refer to the research method used in the study: [CS] Case Study, [S] Survey, [A] Archival, [QE] Quasi-experiment, and [E] Experiment. 
Table 5. Consequences of CPM systems on performance

CPM system type A

CPM system type B

CPM system type C

CPM system type D

Reported performance (based on information internally or externally reported)

- Financial performance

- [--, S] Ittner, Larcker, and Randall (2003); [+/-, S] Braam and Nijssen

(2004); [+, CS] Cruz et al. (2011); [+, A]

Ittner and Larcker (1998);

- Moderated by the CPM system design

and use $[+$, S] (Braam and Nijssen, 2004)
[+, QE] Davis and Albright (2004); [+, S] [+/-, S] Kihn (2007)

Moderated by perceived environmenta change $[+$, S] (Kihn, 2007)
- Stock market performance

- Non-financia performance

[+, CS] Cruz et al. (2011);
- [+, S] Ittner, Larcker and Randall (2003)

\section{- $[+$, S $]$ Crabtree and DeBusk (2008)}

Perceived performance (based on responses from research participants)

- Perceived financial and - [+, S] Bisbe and Otley (2004); [+, S]

non-financial

Chenhall and Langfield-Smith (1998); [+,

CS] Cruz et al. (2011); [+, S] De Geuser

et al. (2009); [+, S] Evans (2004); [+, S ]

Hoque (2004); $[+, S]$ Hoque and James

S] Van der Stede et al. (2006); [+, CS]

De Waal et al. (2009)

Moderated by strategic orientation [+/-, S] (Van der Stede et al., 2006) [+, S] (Chenhall and Langfield-Smith, 1998) the maturity of the CPM system $[+, \mathrm{S}]$ (Evans, 2004) [+, CS] (De Waal et al., 2009); the organizational additional use of other management techniques and accounting practices $[+, \mathrm{S}]($ Chenhall an Langfield-Smith, 1998); mechanistic
- [+/-, QE] Griffith and Neely (2009); [+, A] Banker et al. (2000); [--,A] HassabElnaby et al. (2005); [+/-, S] Ittner and Larcker (1997); [--, A] Said et al. (2003)

- Moderated by managerial experience [+ $\mathrm{QE}]$ and the design, implementation, an use of the CPM [+--, QE] (Griffith and Neely, 2009), as well as by the use of inappropriate performance measures [S], unfocused strategy plans [-, S], decreased flexibility of the contro system [-, S], bureaucracy [-, S], strategic orientation [+/-, S], and industry [+/-, S] (Ittner and Larcker, 1997)

- $[+, \mathrm{A}]$ HassabElnaby et al. (2005); [+, A] Said et al. (2003)

- Moderated by firm characteristics [t-,

A] (HassabElnaby et al., 2005; Said et al., 2003)

- $[+, \mathrm{A}]$ Banker et al. (2000), [+/-, QE Griffith and Neely (2009)

- Moderated by CPM effective design, implementation, and use $[+, \mathrm{QE}]$ and managerial experience $[+, \mathrm{QE}]$ (Griffith and Neely, 2009)

- $[+$, CS] Decoene and Bruggeman (2006); [--, CS] Jazayeri and Scapens (2008); [+/CS] Ukko et al. (2007)

- Influenced by degree of CPM strategic alignment [+, CS] and CPM effective design $[+, \mathrm{CS}]$ (Decoene and Bruggeman, 2006); organizational culture [+, CS managerial education level [+, CS], managerial experience $[+, \mathrm{CS}]$, and the maturity of the CPM system [+, CS (Ukko et al., 2007) 
Geuser et al., 2009); CPM use

(interactive way) $[+, \mathrm{S}]$ (Bisbe and Otley,

2004); firm size [+, S], product life cycle

stage $[+, \mathrm{S}]$, market position $[+, \mathrm{S}]$

(Hoque and James, 2000)

- Perceived financial performance

- Performance improvement

\section{- Strategic goals}

achievement

- Strategic outcomes in terms of delivery,

flexibility, and low cost

- Customer performance

- [+/-, S] Hyvonen (2007); [+, CS] Cruz et al. (2011)

- Moderated by the use of information

technology [+, S] and customer strategy

- [+/-, S] Braam and Nijssen (2004); [+, S] Grafton et al. (2010); [+, S] Henri,

- (2006b); [--, S] Perera et al. (1997) diagnostic/interactive CPM use [+, S], the use of CPM in an interactive way [+ $\mathrm{S}]$, and an increased emphasis on market orientation [+, S] (Henri, 2006b).

Moderated by strategic orientation [+/-,

S] (Perera et al., 1997)

- [+/-, CS] Johnston et al. (2002); [+/-, CS Godener and Soderquist (2004); [+, CS]

Wouters and Wilderom (2008)

- Moderated by the way in which the CPM was developed and used $[+, \mathrm{CS}]$

Johnston et al., 2002, Wouters and

CPM system [+, CS], the managerial

educational level (Ukko et al., 2007)

[+, S] (Hyvonen, 2007)
- $[+/-$, CS] Malina and Selto (2001); [+/-, CS] Ukko et al. (2007)

- Mediated by CPM meeting the

characteristics of an effective

management control device $[+, \mathrm{CS}]$ and an effective communication system [+,

CS] (Malina and Selto, 2001)

- Influenced by organizational culture [+, CS], managerial education level [+, CS ], managerial experience $[+, \mathrm{CS}]$, and the maturity of the CPM system [+, CS

(Ukko et al., 2007)
- $[+$, CS $]$ Papalexandris et al. (2004)

- $[+$, CS $]$ McAdam and Bailie (2002)
[+/-, CS] Ukko et al. (2007)

- Influenced by organizational culture [+, $\mathrm{CS}]$, managerial education level [+, CS] managerial experience $[+, \mathrm{CS}]$, and the managerial experience $[+, \mathrm{CS}]$, and (Ukko et al., 2007)
[+, S] Chenhall (2005)

Mediated by the effects of organizational

learning $[+, \mathrm{S}]$ and strategic alignment $[+$

S] (Chenhall, 2005)

- Team pert 
- Project performance in product developmen

contexts

Davila $(2000)$

Moderated by product uncertainty

CS], product differentiation strategy [+/-,

$\mathrm{CS}]$, and purpose of the measurement

system organization structure [+/-, CS

Davila (2000)
Managerial performance
- Managerial performance

\section{- [+, S] Burney and Widener (2007); [+, S] - [-, S] Cheng et al. (2007)}

- Mediated by perceived role conflict [+,

Hall $(2008,2010)$

$\mathrm{S}]$ and perceived goal difficulty $[+, \mathrm{S}]$

Mediated by goal clarity $[+, S]$ and

(Cheng et al., 2007)

psychological empowerment in

eaning $[+$, S $]$ (Hall, 2008); role

ambiguity $[-$, S $]$ (Burney and Widener,

(Hall, 2010)

\section{Inter-firm performance}

- Perceived inter-

firm/relationship

- [+, S] Cousins et al. (2008); [+, S]

performance

Mahama (2006)

Mediated by cooperation and

Mahama, 2006)

\section{socialization [+, S] (Cousins et al., 2008;}

Notes: The sign within [] refers to the type of impact found in the study: [+] refers to positive effects; [-] refers to negative effects; [+/-] refers to mixed effects; [--] refers to no effects found; [ - refers to

curvilinear effects. The abbreviations within [] refer to the research method used in the study: [CS] Case Study, [S] Survey, [A] Archival, [QE] Quasi-experiment, and [E] Experiment.

- $[+$, S] Burney et al. (2009)

- Mediated by organizational citizenship

behaviours [+, S] (Burney et al., 2009) 
Figure 1. Conceptual framework about the impact of CPM

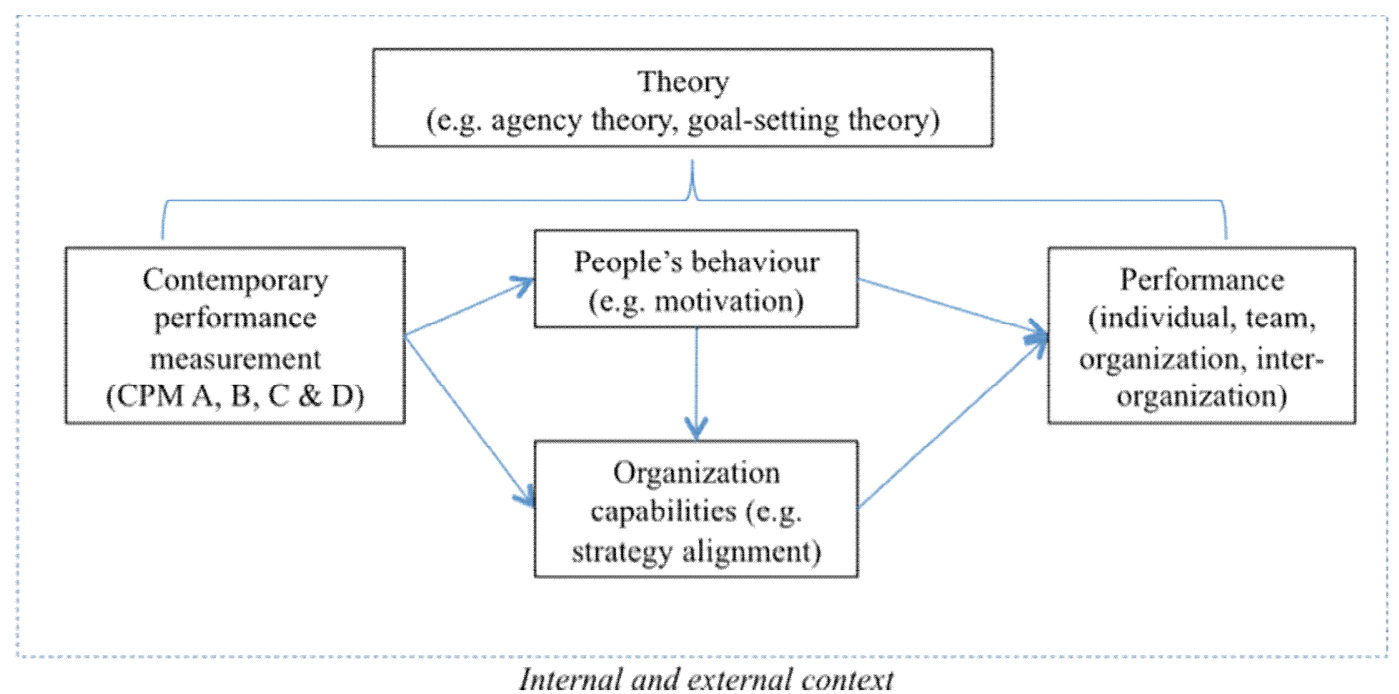




\section{Appendix}

Table A.1. Summary of studies selected

\begin{tabular}{|c|c|c|c|c|c|c|c|c|c|c|c|}
\hline Author & Date & Area & $\begin{array}{l}\text { CPM system } \\
\text { type }\end{array}$ & $\begin{array}{l}\text { Theoretical } \\
\text { background }\end{array}$ & Data collection & Data analysis & $\begin{array}{l}\text { CPM system } \\
\text { consequences }\end{array}$ & Contextual variables & Industry & Country & $\begin{array}{l}\text { Level of } \\
\text { analysis }\end{array}$ \\
\hline Ahn, H. & 2001 & $\begin{array}{l}\text { STR/M } \\
\text { NG }\end{array}$ & CPM B [BSC] & $\mathrm{NE}$ & $\begin{array}{l}\text { Case study (1 } \\
\text { firm) }\end{array}$ & $\mathrm{NE}$ & $\begin{array}{l}\text { - } \text { Communication } \\
\text { - Management practices } \\
\text { - Strategic alignment } \\
\text { - Strategic focus } \\
\text { - Strategy development/ } \\
\text { continuous process } \\
\text { - Organizational learning } \\
\text { - Time consuming } \\
\text { (complexity) }\end{array}$ & $\begin{array}{l}\text { - Environmental risk } \\
\text { - Managers' cognitive } \\
\text { limitations }\end{array}$ & Manufacturing & Germany & Organization \\
\hline $\begin{array}{l}\text { Banker, R.; } \\
\text { Chang, H.; } \\
\text { Pizzini, M. }\end{array}$ & 2004 & $\mathrm{ACC}$ & CPM C [BSC] & $\begin{array}{l}\text { Cognitive } \\
\text { limitations and } \\
\text { information } \\
\text { processing theories }\end{array}$ & $\begin{array}{l}\text { Experiment } \\
\text { (480 MBA } \\
\text { students) }\end{array}$ & $\begin{array}{l}\text { T-test and } \\
\text { regression } \\
\text { analysis }\end{array}$ & $\begin{array}{l}\text { - Performance evaluation } \\
\text { bias (common measures } \\
\text { bias) }\end{array}$ & $\begin{array}{l}\text { - Managerial knowledge } \\
\text { of strategic objectives }\end{array}$ & NA & US & Individual \\
\hline $\begin{array}{l}\text { Banker, R.; } \\
\text { Potter, G.; } \\
\text { Srinivasan, D. }\end{array}$ & 2000 & ACC & CPM D & Agency theory & $\begin{array}{l}\text { Archival } \\
\text { research (18 } \\
\text { hotels) }\end{array}$ & $\begin{array}{l}\text { Regression } \\
\text { analysis }\end{array}$ & $\begin{array}{l}\text { - Financial and non- } \\
\text { financial performance }\end{array}$ & & Hotel & US & Business unit \\
\hline $\begin{array}{l}\text { Bisbe, J.; Otley, } \\
\text { D. }\end{array}$ & 2004 & ACC & $\begin{array}{l}\text { CPM A } \\
{[\text { LoC] }}\end{array}$ & NE & $\begin{array}{l}\text { Survey ( } 40 \\
\text { CEOs of } \\
\text { medium-sized } \\
\text { firms) }\end{array}$ & $\begin{array}{l}\text { Correlation, } \\
\text { regression } \\
\text { analyses }\end{array}$ & $\begin{array}{l}\text { - Innovation capabilities } \\
\text { - Perceived financial and } \\
\text { non-financial } \\
\text { performance }\end{array}$ & - CPM use (interactive) & Manufacturing & Spain & Organization \\
\hline $\begin{array}{l}\text { Bititci, U.; } \\
\text { Mendibil, K.; } \\
\text { Nudurapati, S.; } \\
\text { Garengo, P.; } \\
\text { Turner, T. }\end{array}$ & 2006 & OPS & CPM A & $\mathrm{NE}$ & $\begin{array}{l}\text { Case study ( } 5 \\
\text { firms) }\end{array}$ & $\mathrm{NE}$ & $\begin{array}{l}\text { - Leadership/management } \\
\text { style } \\
\text { - Organizational culture }\end{array}$ & & Manufacturing & UK & Organization \\
\hline $\begin{array}{l}\text { Braam, G.; } \\
\text { Nijssen, E. }\end{array}$ & 2004 & $\begin{array}{l}\text { STR/M } \\
\text { NG }\end{array}$ & CPM A [BSC] & $\mathrm{NE}$ & $\begin{array}{l}\text { Survey ( } 41 \mathrm{~b} 2 \mathrm{~b} \\
\text { firms) }\end{array}$ & $\begin{array}{l}\text { Regression } \\
\text { analysis }\end{array}$ & $\begin{array}{l}\text { - Financial performance } \\
\text { - Perceived financial } \\
\text { performance }\end{array}$ & - CPM design and use & $\begin{array}{l}\text { Various } \\
\text { industries }\end{array}$ & Netherlands & Organization \\
\hline $\begin{array}{l}\text { Burney, L; } \\
\text { Widener, S. }\end{array}$ & 2007 & ACC & СРM B & $\begin{array}{l}\text { Goal-setting theory } \\
\text { and role stressors } \\
\text { theory }\end{array}$ & $\begin{array}{l}\text { Survey (700 } \\
\text { IMA members) }\end{array}$ & SEM & $\begin{array}{l}\text { - Managerial performance } \\
\text { - Role ambiguity } \\
\text { - Job relevant information } \\
\text { - Role conflict }\end{array}$ & $\begin{array}{l}\text { - Managerial experience } \\
\text { - Complexity (number of } \\
\text { performance measures) } \\
\text { - Coupling of CPM }\end{array}$ & $\begin{array}{l}\text { Various } \\
\text { industries }\end{array}$ & US & Individual \\
\hline
\end{tabular}




\begin{tabular}{|c|c|c|c|c|c|c|c|c|c|c|c|}
\hline Author & Date & Area & $\begin{array}{l}\text { CPM system } \\
\text { type }\end{array}$ & $\begin{array}{l}\text { Theoretical } \\
\text { background }\end{array}$ & Data collection & Data analysis & $\begin{array}{l}\text { CPM system } \\
\text { consequences }\end{array}$ & Contextual variables & Industry & Country & $\begin{array}{l}\text { Level of } \\
\text { analysis }\end{array}$ \\
\hline & & & & & & & & $\begin{array}{l}\text { system to evaluation/ } \\
\text { compensation processes } \\
\text { (i.e., CPM D) }\end{array}$ & & & \\
\hline $\begin{array}{l}\text { Burney, L; } \\
\text { Henle, C.; } \\
\text { Widener, S. }\end{array}$ & 2009 & $\mathrm{ACC}$ & CPM D & $\begin{array}{l}\text { Process control } \\
\text { theory and equity } \\
\text { theory }\end{array}$ & $\begin{array}{l}\text { Survey ( } 242 \\
\text { employees from } \\
53 \text { branches) }\end{array}$ & SEM & $\begin{array}{l}\text { - Organizational } \\
\text { citizenship behaviours } \\
\text { - Managerial performance } \\
\text { - Perceptions of fairness/ } \\
\text { justice }\end{array}$ & $\begin{array}{l}\text { - Technical validity of } \\
\text { performance measures } \\
\text { - Cause-and-effect } \\
\text { validity of performance } \\
\text { measures }\end{array}$ & $\begin{array}{l}\text { Financial } \\
\text { services }\end{array}$ & US & Individual \\
\hline $\begin{array}{l}\text { Butler, A.; Letza, } \\
\text { S.; Neale, B. }\end{array}$ & 1997 & $\begin{array}{l}\mathrm{STR} / \mathrm{M} \\
\mathrm{NG}\end{array}$ & CPM A [BSC] & $\mathrm{NE}$ & $\begin{array}{l}\text { Case study (1 } \\
\text { firm) }\end{array}$ & $\mathrm{NE}$ & $\begin{array}{l}\text { - Participation } \\
\text { - Communication } \\
\text { - Strategic focus } \\
\text { - Cost/time consuming }\end{array}$ & & Manufacturing & UK & Organization \\
\hline $\begin{array}{l}\text { Cardinaels, E.; } \\
\text { Van Veen-Dirks } \\
\text { P. }\end{array}$ & 2010 & $\mathrm{ACC}$ & CPM C $[\mathrm{BSC}]$ & $\begin{array}{l}\text { Cognitive } \\
\text { limitations and } \\
\text { information } \\
\text { processing theories }\end{array}$ & $\begin{array}{l}\text { Experiment } \\
\text { (144 worker } \\
\text { students) }\end{array}$ & $\begin{array}{l}2 \times 4 \text { between- } \\
\text { subject design } \\
\text { ANOVA }\end{array}$ & $\begin{array}{l}\text { - Performance evaluation } \\
\text { bias (common measures } \\
\text { bias) }\end{array}$ & - BSC format & NA & Netherlands & Individual \\
\hline $\begin{array}{l}\text { Cheng, M.; } \\
\text { Luckett, P.; } \\
\text { Mahama, H. }\end{array}$ & 2007 & ACC & CPM C & Goal-setting theory & $\begin{array}{l}\text { Survey (44 sales } \\
\text { consult.) }\end{array}$ & PLS & $\begin{array}{l}\text { - Managerial performance } \\
\text { - Goal conflict }\end{array}$ & - Perceived goal difficulty & Telecom & Australia & Individual \\
\hline Chenhall, R. & 2005 & $\mathrm{ACC}$ & СРМ B & $\begin{array}{l}\text { Competitive } \\
\text { advantage theory, } \\
\text { organizational } \\
\text { learning theory }\end{array}$ & $\begin{array}{l}\text { Survey ( } 80 \mathrm{BU} \\
\text { managers) }\end{array}$ & PLS & $\begin{array}{l}\text { - Strategic alignment } \\
\text { Organizational learning } \\
\text { - Strategic outcomes in } \\
\text { terms of delivery, } \\
\text { flexibility, and low cost }\end{array}$ & - Strategic orientation & $\begin{array}{l}\text { Various } \\
\text { industries }\end{array}$ & Australia & Organization \\
\hline $\begin{array}{l}\text { Chenhall, R.; } \\
\text { Langfield-Smith, } \\
\text { K. }\end{array}$ & 1998 & ACC & CPM A $[\mathrm{BSC}]$ & Contingency theory & $\begin{array}{l}\text { Survey (78 } \\
\text { responses) }\end{array}$ & $\begin{array}{l}\text { Cluster } \\
\text { analysis }\end{array}$ & $\begin{array}{l}\text { - Perceived financial and } \\
\text { non financial } \\
\text { performance }\end{array}$ & $\begin{array}{l}\text { - Strategic orientation } \\
\text { - Management techniques } \\
\text { - Management accounting } \\
\text { practices }\end{array}$ & Manufacturing & Australia & Organization \\
\hline $\begin{array}{l}\text { Cousins, P.; } \\
\text { Lawson, B.; } \\
\text { Squire, B. }\end{array}$ & 2008 & OPS & CPM A & $\mathrm{NE}$ & $\begin{array}{l}\text { Survey (142 } \\
\text { firms) }\end{array}$ & SEM & $\begin{array}{l}\text { - Socialization } \\
\text { - Perceived inter- } \\
\text { firm/relationship } \\
\text { performance (market } \\
\text { share, time to market, } \\
\text { lead-time reduction) }\end{array}$ & & $\begin{array}{l}\text { Manufacturing } \\
\text { and service }\end{array}$ & UK & $\begin{array}{l}\text { Beyond the } \\
\text { organization }\end{array}$ \\
\hline $\begin{array}{l}\text { Crabtree, A.; } \\
\text { DeBusk, G. }\end{array}$ & 2008 & $\mathrm{ACC}$ & CPM B $[\mathrm{BSC}]$ & $\mathrm{NE}$ & $\begin{array}{l}\text { Survey and } \\
\text { Archival (107 } \\
\text { IMA managers) }\end{array}$ & $\begin{array}{l}\text { Paired t-test } \\
\text { and Wilcoxon } \\
\text { test }\end{array}$ & $\begin{array}{l}\text { - Financial performance } \\
\text { - Stock market } \\
\text { performance }\end{array}$ & & $\begin{array}{l}\text { Various } \\
\text { industries }\end{array}$ & US & Organization \\
\hline $\begin{array}{l}\text { Cruz, I.; } \\
\text { Scapens, R.; } \\
\text { Major, M. }\end{array}$ & 2011 & $\mathrm{ACC}$ & CPM A & $\begin{array}{l}\text { Social theory } \\
\text { (Glocalization) } \\
\text { Practice theory }\end{array}$ & $\begin{array}{l}\text { Case study } \\
\text { (equity joint } \\
\text { venture, } 39\end{array}$ & $\begin{array}{l}\text { Qualitative } \\
\text { coding, } \\
\text { construction }\end{array}$ & $\begin{array}{l}\text { - Relationships among } \\
\text { headquarters and } \\
\text { subsidiaries }\end{array}$ & - Accountability & Service & Portugal & Organization \\
\hline
\end{tabular}




\begin{tabular}{|c|c|c|c|c|c|c|c|c|c|c|c|}
\hline Author & Date & Area & $\begin{array}{l}\text { CPM system } \\
\text { type }\end{array}$ & $\begin{array}{l}\text { Theoretical } \\
\text { background }\end{array}$ & Data collection & Data analysis & $\begin{array}{l}\text { CPM system } \\
\text { consequences }\end{array}$ & Contextual variables & Industry & Country & $\begin{array}{l}\text { Level of } \\
\text { analysis }\end{array}$ \\
\hline Davila, A. & 2000 & ACC & CPM A & Contingency theory & $\begin{array}{l}\text { Case study (12 } \\
\text { BU, } 7 \text { firms, } \\
\text { semi-structured } \\
\text { project manager } \\
\text { interviews ) }\end{array}$ & $\begin{array}{l}\text { of critical } \\
\text { incident chart }\end{array}$ & $\begin{array}{l}\text { - Communication } \\
\text { - Visibility and } \\
\text { comparability } \\
\text { (standardization) } \\
\text { - Corporate control } \\
\text { - Innovativeness } \\
\text { - Strategic alignment } \\
\text { - Cost/time consuming } \\
\text { - Financial performance } \\
\text { - Non-financial } \\
\text { performance } \\
\text { - Customer performance } \\
\text { - Project performance } \\
\text { (product development } \\
\text { performance) }\end{array}$ & $\begin{array}{l}\text { - Product differentiation } \\
\text { strategy } \\
\text { - Product uncertainty } \\
\text { - Organizational structure } \\
\text { - Purpose of the } \\
\text { performance } \\
\text { measurement system }\end{array}$ & Manufacturing & US/ Europe & $\begin{array}{l}\text { Division } \\
\text { (R\&D) }\end{array}$ \\
\hline $\begin{array}{l}\text { Davis, S.; } \\
\text { Albright, T. }\end{array}$ & 2004 & ACC & CPM B [BSC] & Non Explicit (NE) & $\begin{array}{l}\text { Quasi- } \\
\text { experimental } \\
\text { design }(2 \\
\text { divisions, } 9 \\
\text { branches })\end{array}$ & Wilcoxon test & - Financial performance & & Banking & US & Business unit \\
\hline $\begin{array}{l}\text { De Geuser, F.; } \\
\text { Mooraj, S.; } \\
\text { Oyon, D. }\end{array}$ & 2009 & $\mathrm{ACC}$ & CPM A [BSC] & $\mathrm{NE}$ & Survey (76 Bus) & $\begin{array}{l}\text { Regression } \\
\text { analysis }\end{array}$ & $\begin{array}{l}\text { Perceived organizational } \\
\text { (financial and non- } \\
\text { financial) performance }\end{array}$ & $\begin{array}{l}\text { - Top management } \\
\text { support } \\
\text { - CPM design, } \\
\text { implementation, and use }\end{array}$ & $\begin{array}{l}\text { Various } \\
\text { industries }\end{array}$ & $\begin{array}{l}\text { Switzerland } \\
\text {, UK, } \\
\text { Germany, } \\
\text { Austria, } \\
\text { France, and } \\
\text { Netherlands }\end{array}$ & Organization \\
\hline $\begin{array}{l}\text { De Waal, A.; } \\
\text { Kourtit, K.; } \\
\text { Nijkamp, P }\end{array}$ & 2009 & OPS & CPM A & $\mathrm{NE}$ & $\begin{array}{l}\text { Case study (17 } \\
\text { large } \\
\text { companies, } 52 \\
\text { interviews) }\end{array}$ & $\begin{array}{l}\text { Qualitative } \\
\text { coding, } \\
\text { descriptive } \\
\text { statistics }\end{array}$ & $\begin{array}{l}\text { - Perceived financial and } \\
\text { non-financial } \\
\text { performance }\end{array}$ & - CPM maturity & $\begin{array}{l}\text { Various } \\
\text { industries }\end{array}$ & Netherlands & Organization \\
\hline $\begin{array}{l}\text { Decoene, V.; } \\
\text { Bruggeman, W. }\end{array}$ & 2006 & OPS & CPM D [BSC] & $\begin{array}{l}\text { Agency theory and } \\
\text { expectancy theory }\end{array}$ & $\begin{array}{l}\text { Case study (1 } \\
\text { firm, } 6 \\
\text { interviews) }\end{array}$ & $\begin{array}{l}\text { Qualitative } \\
\text { coding }\end{array}$ & - Motivation & $\begin{array}{l}\text { Strategic alignment } \\
\text { CPM system design } \\
\text { (controllability, noise, } \\
\text { and technical validity of } \\
\text { measures) }\end{array}$ & Manufacturing & Belgium & Division \\
\hline $\begin{array}{l}\text { Dilla, W.; } \\
\text { Steinbart, P. }\end{array}$ & 2005 & ACC & $\begin{array}{l}\text { CPM C, D } \\
\text { [BSC] }\end{array}$ & $\begin{array}{l}\text { Cognitive } \\
\text { limitations and } \\
\text { information } \\
\text { processing theories }\end{array}$ & $\begin{array}{l}\text { Experiment ( } 43 \\
\text { Undergrad. } \\
\text { students) }\end{array}$ & $\begin{array}{l}2 \times 2 \times 2 \\
\text { ANOVA }\end{array}$ & $\begin{array}{l}\text { - Performance evaluation } \\
\text { bias (common measures } \\
\text { bias) } \\
\text { - Bonus allocation bias }\end{array}$ & $\begin{array}{l}\text { - Managerial training and } \\
\text { experience in designing } \\
\text { BSC }\end{array}$ & NA & US & Individual \\
\hline
\end{tabular}




\begin{tabular}{|c|c|c|c|c|c|c|c|c|c|c|c|}
\hline Author & Date & Area & $\begin{array}{l}\text { CPM system } \\
\text { type }\end{array}$ & $\begin{array}{l}\text { Theoretical } \\
\text { background }\end{array}$ & Data collection & Data analysis & $\begin{array}{l}\text { CPM system } \\
\text { consequences }\end{array}$ & Contextual variables & Industry & Country & $\begin{array}{l}\text { Level of } \\
\text { analysis }\end{array}$ \\
\hline $\begin{array}{l}\text { Dossi, A.; } \\
\text { Patelli, L. }\end{array}$ & 2010 & $\begin{array}{l}\text { STR } \\
\end{array}$ & CPM A & Agency theory & $\begin{array}{l}\text { Survey (141 } \\
\text { Italian } \\
\text { subsidiaries) } 13 \\
\text { interviews }\end{array}$ & $\begin{array}{l}\text { Correlation } \\
\text { Regression } \\
\text { analyses }\end{array}$ & $\begin{array}{l}\text { - Relationship between } \\
\text { headquarters and } \\
\text { subsidiary (learning and } \\
\text { dialogue) } \\
\text { - Strategic alignment } \\
\text { - Corporate control }\end{array}$ & & $\begin{array}{l}\text { Various } \\
\text { industries }\end{array}$ & European & Organization \\
\hline Evans, J. & 2004 & OPS & CPM A & $\mathrm{NE}$ & $\begin{array}{l}\text { Survey (105 } \\
\text { firms) }\end{array}$ & $\begin{array}{l}\text { Regression } \\
\text { analysis }\end{array}$ & $\begin{array}{l}\text { - Perceived financial and } \\
\text { non-financial } \\
\text { performance }\end{array}$ & - CPM maturity & $\begin{array}{l}\text { Manufacturing } \\
\text { and service }\end{array}$ & US & Organization \\
\hline $\begin{array}{l}\text { Gimbert, X.; } \\
\text { Bisbe, J.; } \\
\text { Mendoza, X. }\end{array}$ & 2010 & $\mathrm{ACC}$ & CPM A & $\mathrm{NE}$ & $\begin{array}{l}\text { Survey ( } 349 \\
\text { CEOs) }\end{array}$ & $\begin{array}{l}\text { Regression } \\
\text { analysis }\end{array}$ & $\begin{array}{l}\text { - Strategy as a continuous } \\
\text { process (number and } \\
\text { variety of strategic } \\
\text { decisions) }\end{array}$ & & $\begin{array}{l}\text { Various } \\
\text { industries }\end{array}$ & Spain & Organization \\
\hline $\begin{array}{l}\text { Godener, A.; } \\
\text { Soderquist, K. }\end{array}$ & 2004 & OPS & CPM A & $\mathrm{NE}$ & $\begin{array}{l}\text { Case study (3 } \\
\text { large } \\
\text { companies, } 12 \\
\text { interviews) }\end{array}$ & $\begin{array}{l}\text { Qualitative } \\
\text { coding }\end{array}$ & $\begin{array}{l}\text { - Performance } \\
\text { improvement } \\
\text { - Motivation } \\
\text { - Communication } \\
\text { - Organizational learning }\end{array}$ & - Participation & Electronics & France & Business unit \\
\hline $\begin{array}{l}\text { Grafton, J.; } \\
\text { Lillis, A.; } \\
\text { Widener, S. }\end{array}$ & 2010 & $\mathrm{ACC}$ & CPM A & $\begin{array}{l}\text { Resource-based } \\
\text { view, agency, } \\
\text { cognitive } \\
\text { limitations and } \\
\text { information } \\
\text { processing }\end{array}$ & $\begin{array}{l}\text { Survey (183 BU } \\
\text { managers) }\end{array}$ & SEM (MLE) & $\begin{array}{l}\text { - Perceived financial } \\
\text { performance } \\
\text { - Managerial decision- } \\
\text { making } \\
\text { - Strategic capabilities } \\
\text { (exploiting existing } \\
\text { capabilities and } \\
\text { identifying new) }\end{array}$ & & Manufacturing & Australia & Organization \\
\hline $\begin{array}{l}\text { Griffith, R.; } \\
\text { Neely, A. }\end{array}$ & 2009 & $\begin{array}{l}\text { STR/M } \\
\text { NG }\end{array}$ & CPM D [BSC] & Agency theory & $\begin{array}{l}\text { Quasi- } \\
\text { experiment ( } 2 \\
\text { divisions of } 156 \\
\text { branches and } \\
121 \text { branches of } \\
1 \text { firm) }\end{array}$ & $\begin{array}{l}\text { Regression } \\
\text { analysis }\end{array}$ & $\begin{array}{l}\text { - Financial and non- } \\
\text { financial performance }\end{array}$ & $\begin{array}{l}\text { - CPM system design, } \\
\text { implementation, and use } \\
\text { - Managers' years of } \\
\text { experience }\end{array}$ & Distribution & $\begin{array}{l}\text { Europe and } \\
\text { US }\end{array}$ & Business unit \\
\hline Hall, M. & 2008 & $\mathrm{ACC}$ & СРМ В & $\begin{array}{l}\text { Cognitive and } \\
\text { motivation theories }\end{array}$ & $\begin{array}{l}\text { Survey ( } 83 \mathrm{BU} \\
\text { managers) }\end{array}$ & PLS & $\begin{array}{l}\text { - Managerial performance } \\
\text { - Psychological } \\
\text { empowerment } \\
\text { - Role clarity }\end{array}$ & & Manufacturing & Australia & Individual \\
\hline
\end{tabular}




\begin{tabular}{|c|c|c|c|c|c|c|c|c|c|c|c|}
\hline Author & Date & Area & $\begin{array}{l}\text { CPM system } \\
\text { type }\end{array}$ & $\begin{array}{l}\text { Theoretical } \\
\text { background }\end{array}$ & Data collection & Data analysis & $\begin{array}{l}\text { CPM system } \\
\text { consequences }\end{array}$ & Contextual variables & Industry & Country & $\begin{array}{l}\text { Level of } \\
\text { analysis }\end{array}$ \\
\hline Hall, M. & 2010 & ACC & CPM B & $\begin{array}{l}\text { Individual and } \\
\text { organizational } \\
\text { learning theories }\end{array}$ & $\begin{array}{l}\text { Survey ( } 83 \mathrm{BU} \\
\text { managers) }\end{array}$ & PLS & $\begin{array}{l}\text { Managerial performance } \\
\text { Managerial learning } \\
\text { (mental model } \\
\text { confirmation and } \\
\text { building) }\end{array}$ & $\begin{array}{l}\text { - Managerial experience/ } \\
\text { tenure } \\
\text { - Business unit size }\end{array}$ & Manufacturing & Australia & Individual \\
\hline $\begin{array}{l}\text { HassabElnaby, } \\
\text { H.; Said, A.; } \\
\text { Wier, B. }\end{array}$ & 2005 & $\mathrm{ACC}$ & CPM D & $\begin{array}{l}\text { Agency theory and } \\
\text { contingency theory }\end{array}$ & $\begin{array}{l}\text { Archival (91 } \\
\text { firms) }\end{array}$ & $\begin{array}{l}\text { Regression } \\
\text { analysis, Cox } \\
\text { survival } \\
\text { analysis }\end{array}$ & $\begin{array}{l}\text { - Stock market } \\
\text { performance } \\
\text { - Financial performance }\end{array}$ & - Firm characteristics & $\begin{array}{l}\text { Manufacturing } \\
\text { and service }\end{array}$ & US & Organization \\
\hline Henri, J. & $2006 b$ & $\mathrm{ACC}$ & $\begin{array}{l}\text { CPM A } \\
{[\mathrm{LoC}]}\end{array}$ & $\begin{array}{l}\text { Resource-based } \\
\text { view theory }\end{array}$ & $\begin{array}{l}\text { Survey ( } 383 \\
\text { firms - CEO, } \\
\text { CFO, COO, or } \\
\text { senior vice- } \\
\text { presidents) }\end{array}$ & SEM & $\begin{array}{l}\text { - Perceived financial } \\
\text { performance } \\
\text { - Dynamic tension } \\
\text { - Organizational } \\
\text { capabilities in terms of: } \\
\text { market orientation, } \\
\text { organizational learning, } \\
\text { innovativeness, and } \\
\text { entrepreneurship }\end{array}$ & $\begin{array}{l}\text { - CPM use (diagnostic vs. } \\
\text { interactive) } \\
\text { - Environmental } \\
\text { uncertainty } \\
\text { - Organizational culture } \\
\text { (flexibility vs. control } \\
\text { values) } \\
\text { - Organizational size }\end{array}$ & Manufacturing & Canada & Organization \\
\hline Hoque, $\mathrm{Z}$. & 2004 & $\begin{array}{l}\text { STR/M } \\
\text { NG }\end{array}$ & CPM A & Contingency theory & $\begin{array}{l}\text { Survey }(52 \\
\text { responses) }\end{array}$ & Path analysis & $\begin{array}{l}\text { - Perceived financial and } \\
\text { non-financial } \\
\text { performance }\end{array}$ & & $\begin{array}{l}\text { Various } \\
\text { industries }\end{array}$ & Australia & Organization \\
\hline $\begin{array}{l}\text { Hoque, Z.; } \\
\text { James, W. }\end{array}$ & 2000 & $\mathrm{ACC}$ & CPM A [BSC] & Contingency theory & $\begin{array}{l}\text { Survey (66 } \\
\text { CFOs) }\end{array}$ & $\begin{array}{l}\text { Regression } \\
\text { analysis }\end{array}$ & $\begin{array}{l}\text { - Perceived financial and } \\
\text { non-financial } \\
\text { performance }\end{array}$ & $\begin{array}{l}\text { - Firm size } \\
\text { Product life cycle stage } \\
\text { - Market position }\end{array}$ & Manufacturing & Australia & Organization \\
\hline Hyvonen, J. & 2007 & $\mathrm{ACC}$ & CPM A & Contingency theory & $\begin{array}{l}\text { Survey (51 } \\
\text { business units) }\end{array}$ & $\begin{array}{l}\text { Regression } \\
\text { analysis }\end{array}$ & - Customer performance & $\begin{array}{l}\text { - Information technology } \\
\text { - Customer strategy }\end{array}$ & $\begin{array}{l}\text { Forest, metal } \\
\text { and electronics }\end{array}$ & Finland & Business unit \\
\hline $\begin{array}{l}\text { Ittner, C.; } \\
\text { Larcker, D.; } \\
\text { Meyer, M. }\end{array}$ & 2003 & $\mathrm{ACC}$ & CPM D [BSC] & Agency theory, & $\begin{array}{l}\text { Archival (1 } \\
\text { firm, multiple } \\
\text { individuals) } \\
\text { Survey (572 } \\
\text { managers) }\end{array}$ & $\begin{array}{l}\text { Correlation } \\
\text { Regression } \\
\text { analyses }\end{array}$ & $\begin{array}{l}\text { - Subjectivity } \\
\text { Perceived satisfaction } \\
\text { with CPM system }\end{array}$ & & Banking & US & Individual \\
\hline $\begin{array}{l}\text { Ittner, C.; } \\
\text { Larcker, D.; } \\
\text { Randall, T. }\end{array}$ & 2003 & $\mathrm{ACC}$ & $\begin{array}{l}\text { CPM A, B } \\
\text { [BSC] }\end{array}$ & Contingency theory & $\begin{array}{l}\text { Survey ( } 140 \\
\text { executives) }\end{array}$ & $\begin{array}{l}\text { Correlation } \\
\text { Regression } \\
\text { analyses }\end{array}$ & $\begin{array}{l}\text { - Perceived satisfaction } \\
\text { with CPM level } \\
\text { - Stock market } \\
\text { performance } \\
\text { - Financial performance }\end{array}$ & & $\begin{array}{l}\text { Financial } \\
\text { services }\end{array}$ & US & Organization \\
\hline $\begin{array}{l}\text { Ittner, } \\
\text { C.;Larcker, D. }\end{array}$ & 1997 & ACC & CPM D & $\mathrm{NE}$ & $\begin{array}{l}\text { Survey ( } 249 \\
\text { firms) and } \\
\text { interviews ( } 44 \\
\text { firms) }\end{array}$ & $\begin{array}{l}\text { Regression } \\
\text { analysis }\end{array}$ & $\begin{array}{l}\text { Survey: } \\
\text { - Financial performance }\end{array}$ & $\begin{array}{l}\text { Survey: } \\
\text { - Strategic orientation } \\
\text { - Industry } \\
\text { Interviews: }\end{array}$ & $\begin{array}{l}\text { Automotive and } \\
\text { computer }\end{array}$ & $\begin{array}{l}\text { Germany, } \\
\text { Japan, US, } \\
\text { and Canada }\end{array}$ & Organization \\
\hline
\end{tabular}




\begin{tabular}{|c|c|c|c|c|c|c|c|c|c|c|c|}
\hline Author & Date & Area & $\begin{array}{l}\text { CPM system } \\
\text { type }\end{array}$ & $\begin{array}{l}\text { Theoretical } \\
\text { background }\end{array}$ & Data collection & Data analysis & $\begin{array}{l}\text { CPM system } \\
\text { consequences }\end{array}$ & Contextual variables & Industry & Country & $\begin{array}{l}\text { Level of } \\
\text { analysis }\end{array}$ \\
\hline & & & & & & & & $\begin{array}{l}\text { - Unfocused strategic } \\
\text { action plans } \\
\text { - Incorrect performance } \\
\text { measures } \\
\text { - Bureaucracy } \\
\text { - Inflexibility }\end{array}$ & & & \\
\hline $\begin{array}{l}\text { Ittner, C.D.; } \\
\text { Larcker, D.F. }\end{array}$ & 1998 & $\mathrm{ACC}$ & CPM A & $\mathrm{NE}$ & $\begin{array}{l}\text { Archival } \\
\text { research }(1 \\
\text { firm) }\end{array}$ & $\begin{array}{l}\text { Regression } \\
\text { analysis }\end{array}$ & - Financial performance & & Telecom. & US & Business unit \\
\hline $\begin{array}{l}\text { Jazayeri, M.; } \\
\text { Scapens, R. }\end{array}$ & 2008 & $\mathrm{ACC}$ & CPM D & NE & $\begin{array}{l}\text { Case study (1 } \\
\text { firm, } 10 \\
\text { interviews and } \\
\text { secondary data) }\end{array}$ & $\mathrm{NE}$ & $\begin{array}{l}\text { - Organizational culture } \\
\text { - Perceived financial } \\
\text { performance } \\
\text { - Perceived satisfaction } \\
\text { with the CPM system } \\
\text { - Strategic alignment } \\
\text { - Strategic focus } \\
\text { - Strategy as a continuous } \\
\text { process }\end{array}$ & & Aerospace & UK & Organization \\
\hline $\begin{array}{l}\text { Johnston, R.; } \\
\text { Brignall, S.; } \\
\text { Fitzgerald, L. }\end{array}$ & 2002 & OPS & $\begin{array}{l}\text { CPM A [BSC } \\
\text { and KPIs] }\end{array}$ & $\begin{array}{l}\text { Grounded theory } \\
\text { approach }\end{array}$ & $\begin{array}{l}\text { Case study ( } 6 \\
\text { firms, } \\
\text { interviews and } \\
\text { secondary data) }\end{array}$ & $\begin{array}{l}\text { Qualitative } \\
\text { coding }\end{array}$ & $\begin{array}{l}\text { - Performance } \\
\text { improvement } \\
\text { - Organizational learning } \\
\text { - Management practices }\end{array}$ & $\begin{array}{l}\text { - CPM purpose, design, } \\
\text { implementation, and use }\end{array}$ & $\begin{array}{l}\text { Transport, } \\
\text { Consulting, } \\
\text { Hotel, Banking }\end{array}$ & UK & Organization \\
\hline $\begin{array}{l}\text { Kaplan, S.; } \\
\text { Wisner P. }\end{array}$ & 2009 & $\mathrm{ACC}$ & CPM C [BSC] & $\begin{array}{l}\text { Cognitive } \\
\text { limitations and } \\
\text { information } \\
\text { processing theories }\end{array}$ & $\begin{array}{l}\text { Experiment } \\
\text { (177 US MBA } \\
\text { students) }\end{array}$ & ANOVA & $\begin{array}{l}\text { Performance evaluation } \\
\text { bias (common measures } \\
\text { bias) }\end{array}$ & $\begin{array}{l}\text { - BSC format } \\
\text { Managerial knowledge } \\
\text { of strategic objectives }\end{array}$ & NA & US & Individual \\
\hline Kihn, L. & 2007 & $\mathrm{ACC}$ & $\begin{array}{l}\text { CPM C [with } \\
\text { behaviour } \\
\text { controls] }\end{array}$ & $\begin{array}{l}\text { Contingency } \\
\text { theory, control } \\
\text { theory, and agency } \\
\text { theory }\end{array}$ & $\begin{array}{l}\text { Survey and } \\
\text { archival (36 } \\
\text { responses) }\end{array}$ & $\begin{array}{l}\text { Regression } \\
\text { analysis with } \\
\text { interactions }\end{array}$ & $\begin{array}{l}\text { - Financial performance } \\
\text { (short-term profitability) }\end{array}$ & $\begin{array}{l}\text { - Perceived environmental } \\
\text { change }\end{array}$ & Manufacturing & Finland & Business unit \\
\hline Kolehmainen, $\mathrm{K}$ & 2010 & STR & CPM C & $\mathrm{NE}$ & $\begin{array}{l}\text { Case study (1 } \\
\text { multinational } \\
\text { company, } 22 \\
\text { interviews), } \\
\text { Archival }\end{array}$ & $\begin{array}{l}\text { Qualitative } \\
\text { coding }\end{array}$ & $\begin{array}{l}\text { - Subjectivity as a positive } \\
\text { outcome as it enhances } \\
\text { flexibility } \\
\text { - Participation/managerial } \\
\text { empowerment } \\
\text { - Strategic alignment }\end{array}$ & & $\begin{array}{l}\text { Telecom. } \\
\text { industry }\end{array}$ & Finland & Organization \\
\hline $\begin{array}{l}\text { Kraus, K ; Lind, } \\
\text { J. }\end{array}$ & 2010 & $\mathrm{ACC}$ & CPM A & $\mathrm{NE}$ & $\begin{array}{l}\text { Case study (15 } \\
\text { multinational } \\
\text { companies, } 20 \\
\text { interviews) }\end{array}$ & $\begin{array}{l}\text { Qualitative } \\
\text { coding }\end{array}$ & $\begin{array}{l}\text { - Corporate control of } \\
\text { business units }\end{array}$ & & $\begin{array}{l}\text { Various } \\
\text { industries }\end{array}$ & Sweden & Organization \\
\hline
\end{tabular}




\begin{tabular}{|c|c|c|c|c|c|c|c|c|c|c|c|}
\hline Author & Date & Area & $\begin{array}{l}\text { CPM system } \\
\text { type }\end{array}$ & $\begin{array}{l}\text { Theoretical } \\
\text { background }\end{array}$ & Data collection & Data analysis & $\begin{array}{l}\text { CPM system } \\
\text { consequences }\end{array}$ & Contextual variables & Industry & Country & $\begin{array}{l}\text { Level of } \\
\text { analysis }\end{array}$ \\
\hline $\begin{array}{l}\text { Lau, M.; } \\
\text { Sholihin, M. }\end{array}$ & 2005 & ACC & CPM C [BSC] & $\begin{array}{l}\text { Goal-setting } \\
\text { theory, equity } \\
\text { theory }\end{array}$ & $\begin{array}{l}\text { Survey }(70 \\
\text { managers) }\end{array}$ & $\begin{array}{l}\text { Correlation } \\
\text { Regression } \\
\text { analyses }\end{array}$ & $\begin{array}{l}\text { - Job satisfaction } \\
\text { - Trust } \\
\text { - Perceived fairness }\end{array}$ & & Manufacturing & Indonesia & Individual \\
\hline $\begin{array}{l}\text { Lee, C.; Yang, } \\
\text { H. }\end{array}$ & 2010 & $\mathrm{ACC}$ & $\begin{array}{l}\text { CPM A, B \& } \\
\text { D }\end{array}$ & Contingency theory & $\begin{array}{l}\text { Survey (168 } \\
\text { firms) }\end{array}$ & $\begin{array}{l}\text { Correlation } \\
\text { Regression } \\
\text { analyses }\end{array}$ & $\begin{array}{l}\text { - Perceived financial and } \\
\text { non-financial } \\
\text { performance }\end{array}$ & $\begin{array}{l}\text { - Organizational structure } \\
\text { - Competition }\end{array}$ & $\begin{array}{l}\text { Various } \\
\text { industries }\end{array}$ & Taiwan & Organization \\
\hline $\begin{array}{l}\text { Libby, T.; } \\
\text { Salterio, S.; } \\
\text { Webb, A. }\end{array}$ & 2004 & $\mathrm{ACC}$ & CPM C $[\mathrm{BSC}]$ & $\begin{array}{l}\text { Cognitive effort } \\
\text { bias theory, process } \\
\text { accountability } \\
\text { theory, assurance } \\
\text { theory }\end{array}$ & $\begin{array}{l}\text { Experiment } \\
\text { (227 MBA } \\
\text { students) }\end{array}$ & $\begin{array}{l}2 \times 2 \times 2 \\
\text { ANCOVA }\end{array}$ & $\begin{array}{l}\text { - Performance evaluation } \\
\text { bias }\end{array}$ & $\begin{array}{l}\text { - Process accountability } \\
\text { - Perceived quality of } \\
\text { BSC measures/ use of } \\
\text { assurance report }\end{array}$ & NA & Canada & Individual \\
\hline $\begin{array}{l}\text { Liedtka, S.; } \\
\text { Church, B.; Ray, } \\
\text { M. }\end{array}$ & 2008 & $\mathrm{ACC}$ & CPM C $[\mathrm{BSC}]$ & $\begin{array}{l}\text { Cognitive bias } \\
\text { theories and } \\
\text { theories about } \\
\text { responses to } \\
\text { ambiguity }\end{array}$ & $\begin{array}{l}\text { Experiment }(85 \\
\text { management } \\
\text { students) }\end{array}$ & $\begin{array}{l}\text { Planned } \\
\text { comparison } \\
\text { tests }\end{array}$ & $\begin{array}{l}\text { - Performance evaluation } \\
\text { bias }\end{array}$ & $\begin{array}{l}\text { - Evaluator's ambiguity } \\
\text { intolerance }\end{array}$ & NA & US & Individual \\
\hline Lillis, A. & 2002 & $\mathrm{ACC}$ & CPM A & $\mathrm{NE}$ & $\begin{array}{l}\text { Case study ( } 36 \\
\text { profit centre } \\
\text { managers) }\end{array}$ & $\begin{array}{l}\text { Qualitative } \\
\text { coding }\end{array}$ & - Strategy implementation & $\begin{array}{l}\text { - Loose controls } \\
\text { - Technical integration of } \\
\text { performance measures }\end{array}$ & Manufacturing & Australia & Business unit \\
\hline $\begin{array}{l}\text { Lipe, M.; } \\
\text { Salterio, S. }\end{array}$ & 2002 & $\mathrm{ACC}$ & CPM C [BSC] & $\begin{array}{l}\text { Cognitive } \\
\text { limitations and } \\
\text { information } \\
\text { processing theories }\end{array}$ & $\begin{array}{l}\text { Experiment ( } 78 \\
\text { MBA students) }\end{array}$ & $\begin{array}{l}2 \times 2 \times 2 \\
\text { ANOVA }\end{array}$ & $\begin{array}{l}\text { - Performance evaluation } \\
\text { bias (common measures } \\
\text { bias) }\end{array}$ & - BSC format & NA & US & Individual \\
\hline $\begin{array}{l}\text { Lipe, M..; } \\
\text { Salterio, S. }\end{array}$ & 2000 & $\mathrm{ACC}$ & CPM C $[\mathrm{BSC}]$ & $\begin{array}{l}\text { Cognitive } \\
\text { limitations and } \\
\text { information } \\
\text { processing theories }\end{array}$ & $\begin{array}{l}\text { Experiment ( } 58 \\
\text { MBA students) }\end{array}$ & $\begin{array}{l}2 \times 2 \times 2 \\
\text { MANOVA }\end{array}$ & $\begin{array}{l}\text { - Performance evaluation } \\
\text { bias (common measures } \\
\text { bias) }\end{array}$ & & NA & Canada & Individual \\
\hline Mahama, $\mathrm{H}$. & 2006 & ACC & CPM A & $\mathrm{NE}$ & $\begin{array}{l}\text { Survey ( } 73 \\
\text { managers - } \\
\text { supply chain) }\end{array}$ & PLS & $\begin{array}{l}\text { - Socialization } \\
\text { Cooperation } \\
\text { (information sharing, } \\
\text { problem solving, } \\
\text { willingness to adapt to } \\
\text { changes) } \\
\text { - Perceived inter- } \\
\text { firm/relationship } \\
\text { performance }\end{array}$ & & $\begin{array}{l}\text { Mining and } \\
\text { exploration }\end{array}$ & Australia & $\begin{array}{l}\text { Beyond the } \\
\text { organization }\end{array}$ \\
\hline $\begin{array}{l}\text { Malina, M.; } \\
\text { Selto, F. }\end{array}$ & 2001 & ACC & CPM D [BSC $]$ & $\mathrm{NE}$ & $\begin{array}{l}\text { Case study } \\
\text { (semi-structured } \\
\text { interviews and } \\
\text { secondary data) }\end{array}$ & $\begin{array}{l}\text { Qualitative } \\
\text { coding }\end{array}$ & $\begin{array}{l}\text { - Performance } \\
\text { improvement } \\
\text { - Management } \\
\text { - Motivation } \\
\text { - Strategic alignment }\end{array}$ & $\begin{array}{l}\text { - Communication (support } \\
\text { of organizational culture, } \\
\text { valid messages, } \\
\text { knowledge sharing) } \\
\text { - CPM design }\end{array}$ & Manufacturing & US & Business unit \\
\hline
\end{tabular}




\begin{tabular}{|c|c|c|c|c|c|c|c|c|c|c|c|}
\hline Author & Date & Area & $\begin{array}{l}\text { CPM system } \\
\text { type }\end{array}$ & $\begin{array}{l}\text { Theoretical } \\
\text { background }\end{array}$ & Data collection & Data analysis & $\begin{array}{l}\text { CPM system } \\
\text { consequences }\end{array}$ & Contextual variables & Industry & Country & $\begin{array}{l}\text { Level of } \\
\text { analysis }\end{array}$ \\
\hline & & & & & & & - Tensions/conflicts & & & & \\
\hline Malmi, T. & 2001 & ACC & CPM A [BSC] & $\begin{array}{l}\text { Neo- } \\
\text { institutionalism } \\
\text { theory }\end{array}$ & $\begin{array}{l}\text { Case study (17 } \\
\text { firms, } 17 \text { semi- } \\
\text { structured } \\
\text { interviews })\end{array}$ & $\mathrm{NE}$ & $\begin{array}{l}\text { - Perceived satisfaction } \\
\text { with CPM system }\end{array}$ & & $\begin{array}{l}\text { Various } \\
\text { industries }\end{array}$ & Finland & Organization \\
\hline Marginson, D. & 2002 & $\begin{array}{l}\text { STR/ } \\
\text { MNG }\end{array}$ & CPM A [LoC] & $\mathrm{NE}$ & $\begin{array}{l}\text { Case study }(1 \\
\text { firm, } 26 \\
\text { interview } \\
\text { managers })\end{array}$ & $\begin{array}{l}\text { Qualitative } \\
\text { coding }\end{array}$ & $\begin{array}{l}\text { - Tensions/conflicts } \\
\text { - Strategy as a continuous } \\
\text { process } \\
\text { - Innovation }\end{array}$ & - Communication & Telecom. & UK & Organization \\
\hline $\begin{array}{l}\text { McAdam, R.; } \\
\text { Bailie, B. }\end{array}$ & 2002 & OPS & $\begin{array}{l}\text { CPM C [with } \\
\text { behavioural } \\
\text { measures] }\end{array}$ & $\mathrm{NE}$ & $\begin{array}{l}\text { Case study (1 } \\
\text { firm, longitude.) }\end{array}$ & $\begin{array}{l}\text { Qualitative } \\
\text { coding }\end{array}$ & $\begin{array}{l}\text { - Achievement of strategic } \\
\text { goals } \\
\text { - Communication }\end{array}$ & & Manufacturing & Ireland & Organization \\
\hline Moers, F. & 2005 & ACC & CPM D & Agency theory & $\begin{array}{l}\text { Archival (124 } \\
\text { employees from } \\
1 \text { firm) }\end{array}$ & $\begin{array}{l}\text { Regression } \\
\text { analysis }\end{array}$ & $\begin{array}{l}\text { - Perceived evaluation } \\
\text { bias (lenient and } \\
\text { compressed performance } \\
\text { ratings) }\end{array}$ & & Maritime & Netherlands & Individual \\
\hline $\begin{array}{l}\text { Moon, P.; } \\
\text { Fitzgerald, L. }\end{array}$ & 1996 & ACC & CPM D & $\mathrm{NE}$ & $\begin{array}{l}\text { Case study (1 } \\
\text { firm, } 15 \\
\text { interviews) }\end{array}$ & $\begin{array}{l}\text { Qualitative } \\
\text { coding }\end{array}$ & - Strategy implementation & $\begin{array}{l}\text { - CPM system design, } \\
\text { implementation, and use }\end{array}$ & Service & UK & Organization \\
\hline Mundy, J. & 2010 & ACC & CPM C [LoC $]$ & Agency theory & $\begin{array}{l}2 \text { case study (1 } \\
\text { multinational } \\
\text { company, } 24 \\
\text { interviews), and } \\
\text { archival data }\end{array}$ & $\begin{array}{l}\text { Qualitative } \\
\text { coding }\end{array}$ & - Dynamic tension & $\begin{array}{l}\text { - CPM use (interactive vs. } \\
\text { diagnostic) }\end{array}$ & $\begin{array}{l}\text { Financial } \\
\text { service }\end{array}$ & UK & Organization \\
\hline $\begin{array}{l}\text { Papalexandris, } \\
\text { A.; Ioannou, G.; } \\
\text { Prastacos, G. }\end{array}$ & 2004 & $\begin{array}{l}\text { STR/M } \\
\text { NG }\end{array}$ & CPM B [BSC] & $\mathrm{NE}$ & $\begin{array}{l}\text { Case study (1 } \\
\text { firm) }\end{array}$ & $\mathrm{NE}$ & $\begin{array}{l}\text { - Strategic goals } \\
\text { achievement } \\
\text { - Relationships among } \\
\text { departments } \\
\text { - Subjectivity } \\
\text { - Tensions } \\
\text { - Time consuming } \\
\text { - Communication } \\
\text { - Management practices } \\
\text { - Motivation } \\
\text { - Participation }\end{array}$ & - CPM maturity & Software & Greece & Organization \\
\hline
\end{tabular}




\begin{tabular}{|c|c|c|c|c|c|c|c|c|c|c|c|}
\hline Author & Date & Area & $\begin{array}{l}\text { CPM system } \\
\text { type }\end{array}$ & $\begin{array}{l}\text { Theoretical } \\
\text { background }\end{array}$ & Data collection & Data analysis & $\begin{array}{l}\text { CPM system } \\
\text { consequences }\end{array}$ & Contextual variables & Industry & Country & $\begin{array}{l}\text { Level of } \\
\text { analysis }\end{array}$ \\
\hline $\begin{array}{l}\text { Perera, S.; } \\
\text { Harrison, G.; } \\
\text { Poole, M. }\end{array}$ & 1997 & ACC & CPM A & Contingency theory & $\begin{array}{l}\text { Survey }(109 \\
\text { firms) }\end{array}$ & $\begin{array}{l}\text { Regression } \\
\text { analysis with } \\
\text { interaction } \\
\text { effects }\end{array}$ & $\begin{array}{l}\text { - Perceived financial } \\
\text { performance }\end{array}$ & - Strategic orientation & Manufacturing & Australia & Organization \\
\hline $\begin{array}{l}\text { Roberts, M.; } \\
\text { Albright, T.; } \\
\text { Hibbets, A. }\end{array}$ & 2004 & $\mathrm{ACC}$ & $\begin{array}{l}\text { CPM C, D } \\
\text { [BSC] }\end{array}$ & $\begin{array}{l}\text { Cognitive } \\
\text { limitations and } \\
\text { information } \\
\text { processing theories }\end{array}$ & $\begin{array}{l}\text { Experiment ( } 79 \\
\text { MBA students) }\end{array}$ & $\begin{array}{l}2 \times 2 \times 2 \\
\text { ANOVA }\end{array}$ & $\begin{array}{l}\text { - Performance evaluation } \\
\text { bias (common measures } \\
\text { bias) } \\
\text { - Bonus allocation bias }\end{array}$ & - BSC format & Service & US & Individual \\
\hline $\begin{array}{l}\text { Said, A.; } \\
\text { HassabElnaby, } \\
\text { H.; Wier, B. }\end{array}$ & 2003 & ACC & CPM D & $\begin{array}{l}\text { Agency theory and } \\
\text { contingency theory }\end{array}$ & $\begin{array}{l}\text { Archival (91 } \\
\text { firms) }\end{array}$ & $\begin{array}{l}\text { Regression } \\
\text { analysis }\end{array}$ & $\begin{array}{l}\text { - Stock market } \\
\text { performance } \\
\text { - Financial performance }\end{array}$ & - Firm characteristics & $\begin{array}{l}\text { Manufacturing } \\
\text { and service }\end{array}$ & US & Organization \\
\hline $\begin{array}{l}\text { Sandstrom, J.; } \\
\text { Toivanen, J. }\end{array}$ & 2002 & OPS & CPM B [BSC] & $\mathrm{NE}$ & $\begin{array}{l}\text { Case study }(1 \\
\text { firm - Product } \\
\text { develop. } \\
\text { engineers) }\end{array}$ & $\mathrm{NE}$ & $\begin{array}{l}\text { - Motivation } \\
\text { - Sommunication } \\
\text { Strategic focus } \\
\text { - Strategic alignment } \\
\text { - Participation }\end{array}$ & & Manufacturing & Finland & $\begin{array}{l}\text { Division } \\
\text { (R\&D) }\end{array}$ \\
\hline $\begin{array}{l}\text { Schiff, A.; } \\
\text { Hoffman, L. }\end{array}$ & 1996 & ACC & CPM C & Attribution theory & $\begin{array}{l}\text { Experiment ( } 54 \\
\text { executives) }\end{array}$ & $\begin{array}{l}\text { Descriptive } \\
\text { statistics and } \\
\text { MANOVA }\end{array}$ & $\begin{array}{l}\text { - Performance evaluation } \\
\text { bias }\end{array}$ & $\begin{array}{l}\text { - Level of performance } \\
\text { judgements (department } \\
\text { vs. individual) }\end{array}$ & Retail & US & $\begin{array}{l}\text { Individual \& } \\
\text { Team }\end{array}$ \\
\hline $\begin{array}{l}\text { Scott, T.W.; } \\
\text { Tiessen, P. }\end{array}$ & 1999 & $\mathrm{ACC}$ & CPM D & $\mathrm{NE}$ & $\begin{array}{l}\text { Survey ( } 248 \\
\text { responses) }\end{array}$ & Path analysis & - Team performance & $\begin{array}{l}\text { - Participation in target } \\
\text { setting } \\
\text { - Weight of team } \\
\text { performance in } \\
\text { compensation plan }\end{array}$ & $\begin{array}{l}\text { Various } \\
\text { industries }\end{array}$ & Canada & Team \\
\hline $\begin{array}{l}\text { Speckbacher, G.; } \\
\text { Bischof, J.; } \\
\text { Pfeiffer, T. }\end{array}$ & 2003 & $\mathrm{ACC}$ & $\begin{array}{l}\text { CPM A,B and } \\
\mathrm{D}[\mathrm{BSC}]\end{array}$ & $\mathrm{NE}$ & $\begin{array}{l}\text { Survey (174 } \\
\text { Organization) }\end{array}$ & $\begin{array}{l}\text { Descriptive } \\
\text { statistics }\end{array}$ & $\begin{array}{l}\text { - Perceived satisfaction } \\
\text { with CPM system }\end{array}$ & & $\begin{array}{l}\text { Various } \\
\text { industries }\end{array}$ & $\begin{array}{l}\text { Germany, } \\
\text { Austria and } \\
\text { Switzerland }\end{array}$ & Organization \\
\hline Tayler, W. & 2010 & $\mathrm{ACC}$ & CPM C [BSC $]$ & $\begin{array}{l}\text { Motivated } \\
\text { reasoning theory }\end{array}$ & $\begin{array}{l}\text { Experiment } \\
\text { (132 US`MBA } \\
\text { students) }\end{array}$ & $\begin{array}{l}\text { ANOVA and } \\
\text { mediation } \\
\text { analyses }\end{array}$ & $\begin{array}{l}\text { - Strategic initiative } \\
\text { evaluation bias } \\
\text { (motivated reasoning) }\end{array}$ & $\begin{array}{l}\text { - BSC format } \\
\text { - Participation }\end{array}$ & $\mathrm{NA}$ & US & Individual \\
\hline Tuomela, T. & 2005 & $\mathrm{ACC}$ & CPM B [LoC $]$ & $\mathrm{NE}$ & $\begin{array}{l}\text { Case study/ } \\
\text { Action research } \\
(1 \text { firm, } \\
\text { longitudinal } 4 \\
\text { years })\end{array}$ & $\mathrm{NE}$ & $\begin{array}{l}\text { - Strategy as a continuous } \\
\text { process } \\
\text { - Managerial learning } \\
\text { - Communication } \\
\text { - Time consuming } \\
\text { - Workload } \\
\text { - Visibility }\end{array}$ & - CPM use (interactive) & Manufacturing & Finland & Organization \\
\hline
\end{tabular}




\begin{tabular}{|c|c|c|c|c|c|c|c|c|c|c|c|}
\hline Author & Date & Area & $\begin{array}{l}\text { CPM system } \\
\text { type }\end{array}$ & $\begin{array}{l}\text { Theoretical } \\
\text { background }\end{array}$ & Data collection & Data analysis & $\begin{array}{l}\text { CPM system } \\
\text { consequences }\end{array}$ & Contextual variables & Industry & Country & $\begin{array}{l}\text { Level of } \\
\text { analysis }\end{array}$ \\
\hline $\begin{array}{l}\text { Ukko, J.; } \\
\text { Tenhunen, J.; } \\
\text { Rantanen, H. }\end{array}$ & 2007 & OPS & CPM D [BSC] & $\mathrm{NE}$ & $\begin{array}{l}\text { Case studies (8 } \\
\text { firms, } 24 \\
\text { interviews) }\end{array}$ & $\mathrm{NE}$ & $\begin{array}{l}\text { Management practices } \\
\text { (proactive management, } \\
\text { quality management, } \\
\text { decision making, new } \\
\text { routines) } \\
\text { - Perceived financial and } \\
\text { non-financial } \\
\text { performance } \\
\text { (productivity and } \\
\text { efficiency improvement) } \\
\text { - Achievement of strategic } \\
\text { goals } \\
\text { - Performance } \\
\text { improvement } \\
\text { - Leadership (style, } \\
\text { routines, } \\
\text { communication) }\end{array}$ & $\begin{array}{l}\text { - Managerial education } \\
\text { level } \\
\text { - Managerial experience } \\
\text { - CPM maturity } \\
\text { - Organizational culture }\end{array}$ & $\begin{array}{l}\text { Various } \\
\text { industries }\end{array}$ & Finland & Organization \\
\hline $\begin{array}{l}\text { Van der Stede, } \\
\text { W.; Chow, C.; } \\
\text { Lin, T. }\end{array}$ & 2006 & $\mathrm{ACC}$ & CPM A & $\begin{array}{l}\text { Agency theory and } \\
\text { contingency theory }\end{array}$ & $\begin{array}{l}\text { Survey }(128 \\
\text { firms) }\end{array}$ & $\begin{array}{l}\text { Regression } \\
\text { analysis }\end{array}$ & $\begin{array}{l}\text { - Perceived financial and } \\
\text { non-financial } \\
\text { performance }\end{array}$ & $\begin{array}{l}\text { - Business strategy/ } \\
\text { strategic orientation }\end{array}$ & Manufacturing & $\begin{array}{l}\text { US and } \\
\text { Europe }\end{array}$ & Division \\
\hline Webb, A. & 2004 & ACC & СРМ В & Goal-setting theory & $\begin{array}{l}\text { Experiment ( } 56 \\
\text { managers) }\end{array}$ & $\begin{array}{l}\text { Regression } \\
\text { analysis }\end{array}$ & - Goal commitment & $\begin{array}{l}\text { - Manager's self-efficacy } \\
\text { - Goal attractiveness }\end{array}$ & $\mathrm{NA}$ & Canada & Individual \\
\hline Wiersma, E. & 2009 & $\mathrm{ACC}$ & $\begin{array}{l}\text { CPM C } \\
{[\text { BSC] }}\end{array}$ & $\mathrm{NE}$ & $\begin{array}{l}\text { Survey (19 } \\
\text { firms, } 224 \\
\text { managers) }\end{array}$ & $\begin{array}{l}\text { Regression, } \\
\text { factor, } \\
\text { correlation } \\
\text { analysis, }\end{array}$ & $\begin{array}{l}\text { - Managerial decision- } \\
\text { making } \\
\text { - Relationships within and } \\
\text { among departments } \\
\text { - Managerial self- } \\
\text { monitoring }\end{array}$ & & $\begin{array}{l}\text { Manufacturing } \\
\text { and service }\end{array}$ & Netherlands & Individual \\
\hline $\begin{array}{l}\text { Wong-On-Wing, } \\
\text { B.; Guo, L.; Li, } \\
\text { W.; Yang, D. }\end{array}$ & 2007 & ACC & CPM C [BSC $]$ & $\begin{array}{l}\text { Cognitive bias } \\
\text { theories, selective } \\
\text { attention theory, } \\
\text { actor-observer bias } \\
\text { theory, } \\
\text { correspondence } \\
\text { bias theory }\end{array}$ & $\begin{array}{l}\text { Experiment ( } 68 \\
\text { MBA students) }\end{array}$ & $\begin{array}{l}2 \times 2 \times 2 \\
\text { ANOVA }\end{array}$ & $\begin{array}{l}\text { - Performance evaluation } \\
\text { bias }\end{array}$ & $\begin{array}{l}\text { - Manager's role } \\
\text { - Strategy knowledge }\end{array}$ & Retail & China & Individual \\
\hline $\begin{array}{l}\text { Wouters, M.; } \\
\text { Wilderom, C. }\end{array}$ & 2008 & $\mathrm{ACC}$ & CPM A & $\begin{array}{l}\text { Organizational } \\
\text { learning theory and }\end{array}$ & $\begin{array}{l}\text { Case study/ } \\
\text { Action research }\end{array}$ & $\begin{array}{l}\text { Qualitative } \\
\text { coding, }\end{array}$ & $\begin{array}{l}\text { - Performance } \\
\text { improvement (enabling }\end{array}$ & $\begin{array}{l}\text { - CPM system purpose, } \\
\text { design, implementation, }\end{array}$ & Manufacturing & Netherlands & Business unit \\
\hline
\end{tabular}




\begin{tabular}{|c|c|c|c|c|c|c|c|c|c|c|c|}
\hline Author & Date & Area & $\begin{array}{l}\text { CPM system } \\
\text { type }\end{array}$ & $\begin{array}{l}\text { Theoretical } \\
\text { background }\end{array}$ & Data collection & Data analysis & $\begin{array}{l}\text { CPM system } \\
\text { consequences }\end{array}$ & Contextual variables & Industry & Country & $\begin{array}{l}\text { Level of } \\
\text { analysis }\end{array}$ \\
\hline & & & & contingency theory & $\begin{array}{l}\text { (1 firm, } 42 \\
\text { employees, } \\
\text { longitude.) }\end{array}$ & $\begin{array}{l}\text { descriptive } \\
\text { statistics and } \\
\text { regression } \\
\text { analysis }\end{array}$ & $\begin{array}{l}\text { CPM) } \\
\text { - Management }\end{array}$ & and use & & & \\
\hline
\end{tabular}

Notes: NE stands for not explicit (we include this abbreviation when the authors do not clearly explain in their paper one or more of the study characteristics comprised in this table). NA stands for not applicable. ACC stands for accounting, STR/MNG stands for strategy and general management, OPS stands for operations. 